Article

\title{
Panax quinquefolium L. Ginsenosides from Hairy Root Cultures and Their Clones Exert Cytotoxic, Genotoxic and Pro-Apoptotic Activity towards Human Colon Adenocarcinoma Cell Line Caco-2
}

\author{
Ewa Kochan ${ }^{1, *(\mathbb{D}}$, Adriana Nowak ${ }^{2, *}{ }^{-1}$, Małgorzata Zakłos-Szyda ${ }^{3}\left(\mathbb{0}\right.$, Daria Szczuka $^{2}$, \\ Grażyna Szymańska ${ }^{1}$ and Ilona Motyl ${ }^{2}$ \\ 1 Pharmaceutical Biotechnology Department, Medical University of Lodz, Muszyńskiego 1, 90-151 Lodz, \\ Poland; grazyna.szymanska@umed.lodz.pl \\ 2 Department of Environmental Biotechnology, Lodz University of Technology, Wólczańska 171/173, \\ 90-924 Lodz, Poland; 203190@edu.p.lodz.pl (D.S.); ilona.motyl@p.lodz.pl (I.M.) \\ 3 Institute of Molecular and Industrial Biotechnology, Lodz University of Technology, Stefanowskiego 4/10, \\ 90-924 Lodz, Poland; malgorzata.zaklos-szyda@p.lodz.pl \\ * Correspondence: ewa.kochan@umed.lodz.pl (E.K.); adriana.nowak@p.lodz.pl (A.N.); \\ Tel.: +48-42-677-91-91 (E.K.); +48-42-631-34-84 (A.N.)
}

Academic Editors: Marcello Locatelli, Simone Carradori and Andrei Mocan Received: 9 April 2020; Accepted: 7 May 2020; Published: 11 May 2020

\begin{abstract}
American ginseng, Panax quinquefolium (L.), is traditionally used in folk medicine. It exhibits a range of anti-inflammatory, hepatoprotective, anti-diabetic, anti-obesity, anti-hyperlipidemic and anti-carcinogenic effects. Its main components are ginsenosides, also known as panaxosides or triterpene saponins. In order to obtain high yields of ginsenosides, different methods of controlled production are involved, i.e., with hairy root cultures. However, they are still employed under in vitro conditions. Our studies revealed that hairy root cultures subjected to an elicitation process can be considered as a potent source of ginsenosides. The present study examines the biological activity of ginseng hairy root cultures against the Caco-2 human adenocarcinoma cell line. Among our six different clones of P. quinquefolium hairy roots, extracts B and Be (treated with elicitor) were the strongest inhibitors of the cellular metabolic activity. While all extracts induced DNA damage, $\mathrm{B}$ and $\mathrm{B} e$ also generated reactive oxygen species (ROS) in a concentration-dependent manner, which was correlated with the depletion of the mitochondrial membrane potential and induction of apoptosis. These findings indicate that further research concerning P. quinquefolium hairy root cultures should focus on the activity of rare ginsenosides and other biologically active compound profiles (i.e., phenolic compounds).
\end{abstract}

Keywords: Panax quinquefolium L.; hairy roots; ginsenosides; cytotoxicity; genotoxicity; apoptosis; necrosis; mitochondrial membrane potential; ATP; Caco-2

\section{Introduction}

Plants with healing properties have been applied in medicine and folk herbal practices for centuries. One species used for hundreds of years for its therapeutic properties is American ginseng, known as Panax quinquefolium (L.) Alph. Wood (synonym Panax quinquefolius (L.), Aralia quinquefolia (L.) Decne. E Planch, Ginseng quinquefolium (L.) Alph. Wood, Panax americanus (Raf.) Raf., Panax cuneatus Raf.) [1]. Ginseng roots and their extracts are used in pharmacy and cosmetics and as functional foods or dietary supplements. In 2015, the American Council for Responsible Nutrition reported that 31\% of the consumers used herbal supplements to cope with various health problems and ginseng was 
ranked fourth among leading dietary supplements. It is also added to beverages, smoothies or green drinks to enhance their health beneficial properties.

Ginseng exhibits various anti-inflammatory, hepatoprotective, anti-diabetic, anti-obesity, anti-hyperlipidemic and anti-carcinogenic effects, as well as a tonic effect [2]. As the major bioactive ingredients of ginseng are ginsenosides, also known as panaxosides or triterpene saponins, the extracts used in industry are usually standardized for the ginsenoside content. Ginsenosides are glycosidic compounds consisting of a non-sugar aglycone part and either single or multiple sugar chains. Three types of aglycones can be distinguished: tetracyclic aglycones such as dammaran (the most important are $20(S)$-protopanaxadiol and $20(S)$-protopanaxatriol), pentacyclic aglycones such as oleanolic acid and tetracyclic aglycones such as ocotillol. The sugar part of the saponin most often includes hexoses (glucose, galactose), 6-deoxyhexoses (furanose, rhamnose), pentoses (arabinose, xylose) or uronic acids (i.e., glucuronic acid); they usually have cyclic structures and form semi-acetic bonds with an aglycone.

Most ginsenosides are glycoside derivatives of dammaran consisting of 17 carbon atoms in a four-ring structure with various sugar residues attached to the positions C-3 and C-20 [3]. Over 30 of the so-called main ginsenosides were identified. They can be divided into two types: $20(S)$-protopanoxadiol (PPD) derivatives and $20(S)$-protopanoxatriol (PPT) derivatives. The PPD derivatives include such metabolites as $\mathrm{Rb} 1, \mathrm{Rb} 2, \mathrm{Rb} 3, \mathrm{Rc}$ and $\mathrm{Rd}$. They are denoted as the $\mathrm{Rb}$ group of ginsenosides. Other ginseng saponins belonging to the PPT derivatives, such as Re, Rf, Rg1, Rg2 and Rh1, are known as the Rg group of ginsenosides [3]. The dammaran-type metabolites, such as the saponins Rh2, Rh3, Rh4, $\mathrm{Rg} 2, \operatorname{Rg} 3, \operatorname{Rg} 5$ and $\mathrm{Rk} 1$, are rare and are referred to as minor ginsenosides. Several reports note that they are naturally present in trace amounts or they are not detected at all. In raw plant material, their level can be altered, enhanced or enriched using several different techniques such as steaming, puffing, fermentation and high-temperature/pressure treatments [4-7].

Ginsenoside F11 (24-R-pseudoginsenoside) is an ocotillol-type saponin, while ginsenoside Ro is pentacyclic [8]. Bioactive phytochemicals from P. quinquefolium, as well as their chemical structure, biochemistry, pharmacological and biological activity, have been thoroughly discussed in a recent review [3].

Previously, the raw material for the production of medicinal ginseng products was obtained from natural sources; however, due to extensive exploitation resulting in ginseng being entered into the "Red Book of Endangered Species" in 1972, new attempts have been made to cultivate ginseng under natural conditions or field conditions. Currently, the high demand for and high prices of ginseng root (from 20 to 1105 USD per kilogram), as well as the inability to obtain this raw material from natural sources, have caused an increase in field ginseng cultivation. However, soil cultivation is very labour-intensive, and at least three or four years is needed to obtain valuable raw material. In addition, due to the need for agro technology and prophylactic plant protection treatments (ginseng is extremely susceptible to fungal diseases and pests), the process is expensive [9-11]. Therefore, in order to obtain plant ginsenosides with high yields, different controlled productions based on the use of hairy root cultures in vitro are under investigation.

Such cultivation methods may be an effective way to obtain valuable secondary metabolites for field crops. Hairy root cultures possess advantages over other cultivation methods [12]. They are characterized by rapid growth (only 28 days) without the need for supplementation with additional phytohormones, which allows a large amount of biomass to be produced in a relatively short time. In addition, they are genetically stable and no drastic decline in metabolite accumulation is observed as the root line grows older. They are distinguished by plagiatropism and a lack of geotropism. Hairy root cultures involve the production of numerous lateral roots with an increased root hair zone, diversified cell structure and structural integration of tissues, which plays a crucial role in the normal course of metabolic processes. This is especially important considering that some metabolites are synthesized only in specialized organs and usually only appear in the above-ground parts of plants. In addition, the approach also offers a relative ease in changing the scale of production, which further increases their value as potential "producers" of desired compounds [13]. 
Our previous investigation indicated that hairy root cultures of P. quinquefolium could serve as an alternative source of plant material for industrial use, as they readily accumulate ginsenosides in the same or higher amounts than traditionally cultivated roots [14,15]. However, knowledge of the active compound content must be supplemented with an understanding of the biological properties of these cultures.

In the present studies, three clones of hairy root cultures of P. quinquefolium (labelled A, B and $\mathrm{G})$ were examined for their biological effects; these were either subjected to a methyl jasmonate elicitation or not. The novelty of this investigation lies in the fact that it examines the genotoxic and cytotoxic potency of the tested extracts towards the Caco-2 human colon adenocarcinoma cell line using a comet assay (measuring DNA damage) and two commercial cytotoxicity assays: MTT (3-(4,5-dimethylthiazolyl-2)-2,5-diphenyltetrazolium bromide) and PrestoBlue. In addition, the cells were subjected to a microscope observation to identify any morphological changes. A clonogenic assay was performed to measure the proliferative capacity of cells after treatment with the P. quinquefolium extracts. To investigate the potential of the extracts as inducers of apoptosis/necrosis, the intracellular ATP level, mitochondrial membrane potential and intracellular oxidative stress were also investigated.

\section{Results and Discussion}

\subsection{Ginsenoside Content in Studied Clones of Hairy Root Cultures of P. quinquefolium}

Three clones of P. quinquefolium hairy roots (A, B and G) were examined to determine their biological properties. Transformation was confirmed by a PCR analysis [16]. This analysis confirmed that the rol $B$ and rol $C$ genes from the Ri plasmid of $A$. rhizogenes became integrated with the genome of the P. quinquefolium hairy roots and thus indicated the presence of integrated T-DNA in the hairy root cultures.

The studied clones differed in terms of morphology (Figure 1) and content of active compounds-ginsenosides (Table 1).

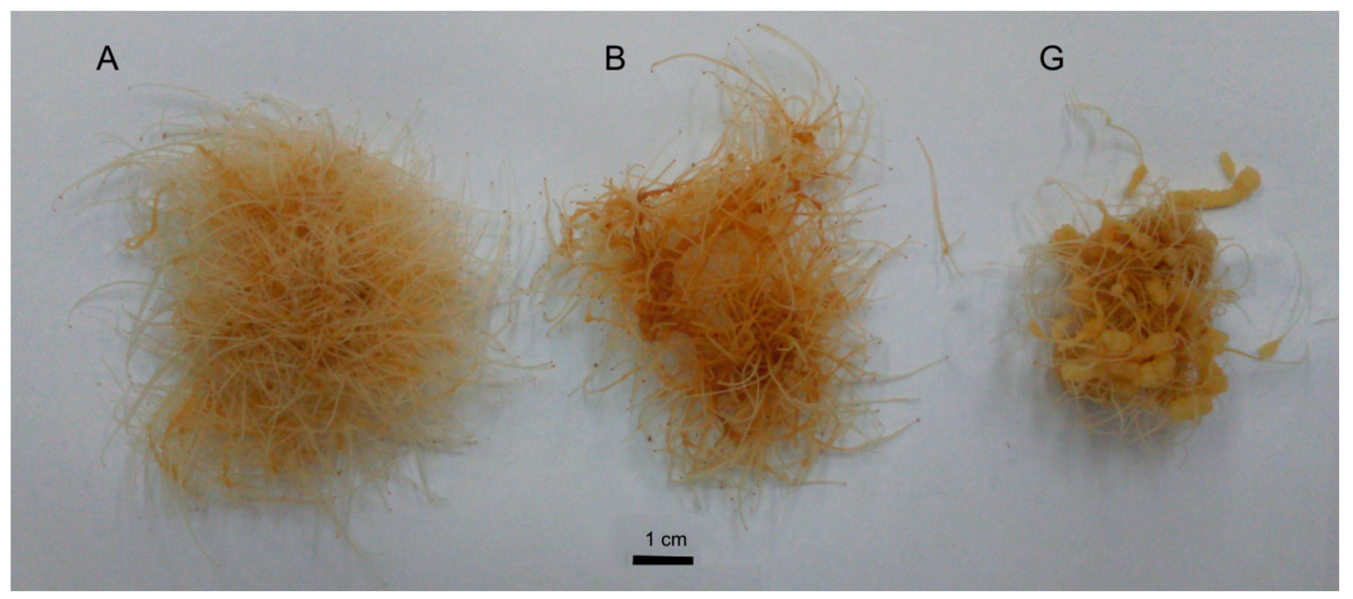

Figure 1. Morphology of A, B and G clones of hairy root cultures of P. quinquefolium after 28-days cultivation.

Line A demonstrated the morphology typical for hairy roots, with thin roots of a light-yellow colour. The roots from line B were also thin; however, their oldest part became brown. Additionally, they achieved a lower biomass production than those of clone A. The roots of clone G were partially thicker and had a callus-like appearance. The extracts in which the level of ginsenosides was examined were derived from the roots cultures that did not undergo an elicitation process (A, B and $G$ ), as well as those subjected to a MeJA elicitation ( $\mathrm{A} e, \mathrm{~B} e$ and $\mathrm{Ge}$ ). The hairy roots that underwent elicitation contained more saponins than those untreated with MeJA (Table 1). 
Table 1. Ginsenoside content in the studied clones of the P. quinquefolium hairy root cultures non-subjected and subjected to elicitation with $250 \mu \mathrm{M}$ MeJa.

\begin{tabular}{|c|c|c|c|c|c|c|c|}
\hline \multirow{2}{*}{\multicolumn{2}{|c|}{ Metabolite }} & \multicolumn{6}{|c|}{ Saponin Content $[\mathrm{mg} / \mathrm{g}$ d.w. $] \pm$ S.E.M. } \\
\hline & & \multirow{2}{*}{$\frac{\mathbf{A}}{1.28 \pm 0.113^{\mathrm{a}}}$} & \multirow{2}{*}{$\frac{\text { B }}{1.04 \pm 0.064^{\mathrm{a}}}$} & \multirow{2}{*}{$\frac{\mathrm{G}}{1.42 \pm 0.037^{\mathrm{a}}}$} & \multirow{2}{*}{$\begin{array}{c}\mathbf{A} \boldsymbol{e} \\
0.79 \pm 0.053^{\mathrm{b}}\end{array}$} & \multirow{2}{*}{$\begin{array}{c}\mathbf{B} \boldsymbol{e} \\
1.41 \pm 0.038^{\mathrm{a}}\end{array}$} & \multirow{2}{*}{$\frac{\mathrm{G} e}{2.00 \pm 0.063^{\mathrm{c}}}$} \\
\hline$\xi$ & $\operatorname{Rg} 1$ & & & & & & \\
\hline 品 & $\operatorname{Re}$ & $2.57 \pm 0.253^{\mathrm{a}}$ & $0.86 \pm 0.037^{b}$ & $1.27 \pm 0.035^{\mathrm{c}}$ & $1.49 \pm 0.030^{\mathrm{d}}$ & $1.22 \pm 0.021^{\mathrm{c}}$ & $1.21 \pm 0.028^{\mathrm{c}}$ \\
\hline & Sum & $3.85 \pm 0.359^{\text {a }}$ & $1.9 \pm 0.101^{b}$ & $2.68 \pm 0.072^{c}$ & $2.28 \pm 0.083^{b}$ & $2.63 \pm 0.048^{c}$ & $3.21 \pm 0.089^{\mathrm{a}}$ \\
\hline \multirow{6}{*}{ 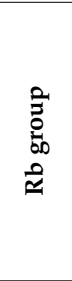 } & $\mathrm{Rb} 1$ & $4.74 \pm 0.162^{a}$ & $1.56 \pm 0.021^{b}$ & $1.64 \pm 0.034^{b}$ & $9.91 \pm 0.200^{c}$ & $8.48 \pm 0.061^{\mathrm{d}}$ & $9.10 \pm 0.282^{c, d}$ \\
\hline & Rc & $4.51 \pm 0.150^{\text {a }}$ & $1.63 \pm 0.194^{\mathrm{b}}$ & $1.35 \pm 0.016^{\mathrm{b}}$ & $6.35 \pm 0.080^{c}$ & $2.67 \pm 0.041^{\mathrm{d}}$ & $1.83 \pm 0.086^{b}$ \\
\hline & $\mathrm{Rb} 2$ & $1.28 \pm 0.039^{\mathrm{a}}$ & $0.34 \pm 0.014^{b}$ & $0.22 \pm 0.005^{c}$ & $3.13 \pm 0.001^{\mathrm{d}}$ & $0.96 \pm 0.038^{\mathrm{e}}$ & $1.10 \pm 0.042^{a, e}$ \\
\hline & $\mathrm{Rb3}$ & $0.76 \pm 0.022^{a}$ & $0.14 \pm 0.014^{\mathrm{b}}$ & $0.08 \pm 0.002^{c}$ & $1.83 \pm 0.011^{\mathrm{d}}$ & $0.48 \pm 0.020^{\mathrm{e}}$ & $0.49 \pm 0.018^{\mathrm{e}}$ \\
\hline & $\mathrm{Rd}$ & $1.88 \pm 0.114^{\mathrm{a}}$ & $0.56 \pm 0.094^{b}$ & $0.31 \pm 0.012^{b}$ & $10.81 \pm 0.141^{\mathrm{c}}$ & $4.94 \pm 0.085^{\mathrm{d}}$ & $5.11 \pm 0.189^{d}$ \\
\hline & Sum & $13.19 \pm 0.311^{\mathrm{a}}$ & $4.22 \pm 0.245^{b}$ & $3.72 \pm 0.046^{\mathrm{b}}$ & $31.99 \pm 0.194^{\mathrm{c}}$ & $17.53 \pm 0.217^{\mathrm{d}}$ & $17.64 \pm 0.611^{\mathrm{d}}$ \\
\hline Total & $\begin{array}{c}\mathrm{Rg}+\mathrm{Rb} \\
\text { group }\end{array}$ & $17.04 \pm 0.646^{a}$ & $6.12 \pm 0.194^{b}$ & $6.27 \pm 0.112^{b}$ & $34.96 \pm 0.278^{c}$ & $20.16 \pm 0.240^{d}$ & $20.85 \pm 0.603^{d}$ \\
\hline
\end{tabular}

The means with the same letter in the row does not differ significantly according to the Kruskall-Wallis test $(p \leq 0.05)$.

The highest levels of total ginsenosides were determined in clone A and Ae (17.04 and $34.96 \mathrm{mg} / \mathrm{g}$ d.w., respectively). Both hairy root cultures were the richest in their Rb saponin content, expressed as the sum of $\mathrm{Rb} 1, \mathrm{Rb} 2, \mathrm{Rb} 3, \mathrm{Rc}$ and $\mathrm{Rd}$; however, the protopanaxadiol derivatives content was 2.4-fold higher in $\mathrm{A} e$ than clone $\mathrm{A}$. In addition, the levels of the $\mathrm{Rb}$ group saponins also increased more than 4-fold in Be and 4.7-fold in Ge, i.e., after stimulation with MeJa, compared with the non-treated samples.

Slightly different findings were obtained for the Rg ginsenosides (expressed as sum of Rg1 and Re). Among the untreated cultures, clone A was found to express the greatest amount of protopanaxatriol derivatives. Among the treated cultures, clone Ge accumulated higher amounts of the Rg group saponins than $\mathrm{A} e$ and $\mathrm{B} e$. Additionally, clone Ae demonstrated lower $\operatorname{Rg} 1+\operatorname{Re}$ than $\mathrm{A}$.

An analysis of the individual saponins showed that the quantitatively dominant compounds were $\mathrm{Rb} 1$ and $\mathrm{Rc}$ (clone $\mathrm{A}$ ), $\mathrm{Rc}$ and $\mathrm{Rb} 1$ (clone $\mathrm{B}$ ) or Rb1 and Rg1 (clone $\mathrm{G}$ ) in the cultures not subjected to elicitation. Further, metabolites $\mathrm{Rb} 1$ and $\mathrm{Rd}$ were found to predominate in all cultures (Ae, $\mathrm{Be}, \mathrm{Ge}$ ) after the MeJA treatment. Our results demonstrate that ginsenoside profiles varied significantly among the hairy root clones both with regard to the type of clone and elicitation status. The untreated clones demonstrated the following ginsenoside profiles: $\mathrm{Rb} 1>\mathrm{Rc}>\mathrm{Re}>\mathrm{Rd}>\mathrm{Rb} 2 / \mathrm{Rg} 1>\mathrm{Rb} 3$ for clone $\mathrm{A}, \mathrm{Rc}$ $>\operatorname{Rb} 1>\operatorname{Rg} 1>\operatorname{Re}>\operatorname{Rd}>\operatorname{Rb} 2>\operatorname{Rb} 3$ for clone $\mathrm{B}$ and $\operatorname{Rb} 1>\operatorname{Rg} 1>\operatorname{Rc}>\operatorname{Re}>\operatorname{Rd}>\operatorname{Rb} 2>\operatorname{Rb} 3$ for clone G. In contrast, the elicited cultures demonstrated quite different profiles: $R d>R b 1>R c>R b 2>R b 3>$ $\operatorname{Re}>\operatorname{Rg} 1$ for $\mathrm{A} e, \operatorname{Rb} 1>\operatorname{Rd}>\operatorname{Rc}>\operatorname{Rg} 1>\operatorname{Re}>\operatorname{Rb} 2>\operatorname{Rb} 3$ for $\mathrm{B} e$ and $\operatorname{Rb} 1>\operatorname{Rd}>\operatorname{Rg} 1>\operatorname{Rc}>\operatorname{Re}>\operatorname{Rb} 2>$ $\mathrm{Rb} 3$ for $\mathrm{Ge}$ (Figure S1).

Elicitation, i.e., the treatment of a culture with an elicitor, is one of the most frequently applied methods used to increase the secondary metabolite production in in vitro cultures. It is based on the subjecting of the studied culture to the activity of the elicitor. An elicitor is a chemical compound that can enhance the synthesis of biologically active compounds in plants by causing defensive reactions. These compounds can be important ingredients from a commercial point of view [17]. In this case, MeJA was used as the elicitor. Saponin production increased twofold in the Ae line and threefold in the $\mathrm{B} e / \mathrm{Ge}$ lines of the P. quinquefolium hairy roots compared with the non-elicited roots. This observation is not surprising considering previous studies $[15,18]$ indicating that MeJA boosted the expression of genes coding key enzymes involved in ginsenoside biosynthesis; more specifically, $250 \mu \mathrm{M}$ MeJA was found to be the most optimal concentration for an effective ginsenoside accumulation [15]. These observations are analogous to in vivo conditions where environmental factors very often strongly influence the production of secondary metabolites; hence, exposure to exogenous methyl jasmonate also influences the ginsenoside production. 
The influence of in vitro elicitation on the content of the secondary metabolites in the hairy root clones was also examined for Gentiana cruciata or Psammosilene tunicoides $[19,20]$. In the present study, the $\mathrm{A}, \mathrm{B}$ and $\mathrm{G}$ root lines not only demonstrated differences in the ginseng saponin production but they were characterized by different morphologies. These disparities can be connected with the random integration of T-DNA into the Ri plasmid in plant tissue. Previous research indicated that even following a successful transformation, the length and copy number of T-DNA inserted into a plant cell varies, resulting in variation in the morphology, genetics, physiology and biochemistry of the resulting clone, i.e., with a different metabolic state and the capacity for the synthesis of secondary metabolites [21,22]. Additionally, some reports on plants from the Araliaceae (for which P. quinquefolium belongs), Solanaceae, Rubiaceae, Vitaceae or Rosaceae indicate that the rol A, rol B and rol C oncogenes, included in T-DNA, are capable to modulate plant growth, cell differentiation and be potential activators of secondary metabolism in transformed cells [21,23].

\subsection{Cytotoxic Activity of P. quinquefolium Extracts}

The cytotoxic activity of the P. quinquefolium extracts towards Caco-2 cells increased together with the rising extract concentration (Figure 2). It could be observed that the highest concentrations of the tested extracts exerted the strongest metabolic inhibitory effect, while the lowest concentrations did not affect the cells significantly.

In the MTT assay, for extract A, the three highest concentrations of MeJa were associated with the greatest decrease in the metabolic activity (up to $98.7 \% \pm 0.2 \%$ ). The lowest values of cytotoxic effects were observed for concentrations lower than $0.136 \mathrm{mg} / \mathrm{mL}$ (Figure 2a). Extract Ae exerted a similar biological activity towards Caco-2 cells to extract A. In the case of extract $\mathrm{B}$, a significant increase in cytotoxicity was observed between concentrations $0.137 \mathrm{mg} / \mathrm{mL}$ and $0.274 \mathrm{mg} / \mathrm{mL}$ (from $17.2 \% \pm 2.6 \%$ to $93.6 \% \pm 4.8 \%$ ) (Figure $2 \mathrm{~b}$ ), together with a significant decrease in cell viability. Extract Be was found to be the greatest inhibitor of Caco-2 metabolic activity, demonstrating toxic effects from a minimum concentration of $0.035 \mathrm{mg} / \mathrm{mL}$. The four highest concentrations demonstrated the greatest inhibition of cell viability (up to $98.9 \% \pm 0.3 \%$ ). Extracts $\mathrm{G}$ and $\mathrm{Ge}$ demonstrated similar effects (Figure 2c); however, at $0.51 \mathrm{mg} / \mathrm{mL}$, Ge had a stronger effect than G. Extracts $\mathrm{G}$ and Ge only exerted a strong cytotoxic activity (approximately 98\%) when administered at the three highest concentrations, as well as the lowest influence on the metabolic activity.

In the PB assay, for extracts $\mathrm{A}$ and $\mathrm{A} e$, a relevant increase in the cytotoxic activity (from $11.2 \%$ $\pm 3.9 \%$ to $86.9 \% \pm 0.3 \%$ ) was observed between concentrations 0.27 and $0.532 \mathrm{mg} / \mathrm{mL}$. The strongest increase in cytotoxicity was observed between the concentrations of 0.27 and $0.54 \mathrm{mg} / \mathrm{mL}$ (Figure 2d). Similar tendencies were observed for extract $\mathrm{B}$ and extract $\mathrm{B} e$ : the strongest cytotoxicity was observed for the highest concentrations (up to approximately $86 \%$ ). For extracts $\mathrm{G}$ and $\mathrm{Ge}$ (Figure $2 \mathrm{f}$ ), a rapid decrease in the metabolic activity (from $10.3 \% \pm 4.0 \%$ to $85.8 \% \pm 0.1 \%$ for extract $\mathrm{G}$ ) was observed, starting from the concentration of $0.51 \mathrm{mg} / \mathrm{mL}$. In the case of $\mathrm{Ge}$, a strong increase of cytotoxicity up to $75.1 \% \pm 9.3 \%$ was observed, starting from the concentration $0.255 \mathrm{mg} / \mathrm{mL}$. The highest concentrations of both extracts were the strongest inhibitors of the metabolic cellular activity (up to approximately $86 \%$ ). Furthermore, extract $\mathrm{G}$ demonstrated the lowest cytotoxic activity among all the studied extracts. Generally, the P. quinquefolium extracts derived from the plant cultures that underwent elicitation displayed a stronger influence on cellular viability than those that did not. 

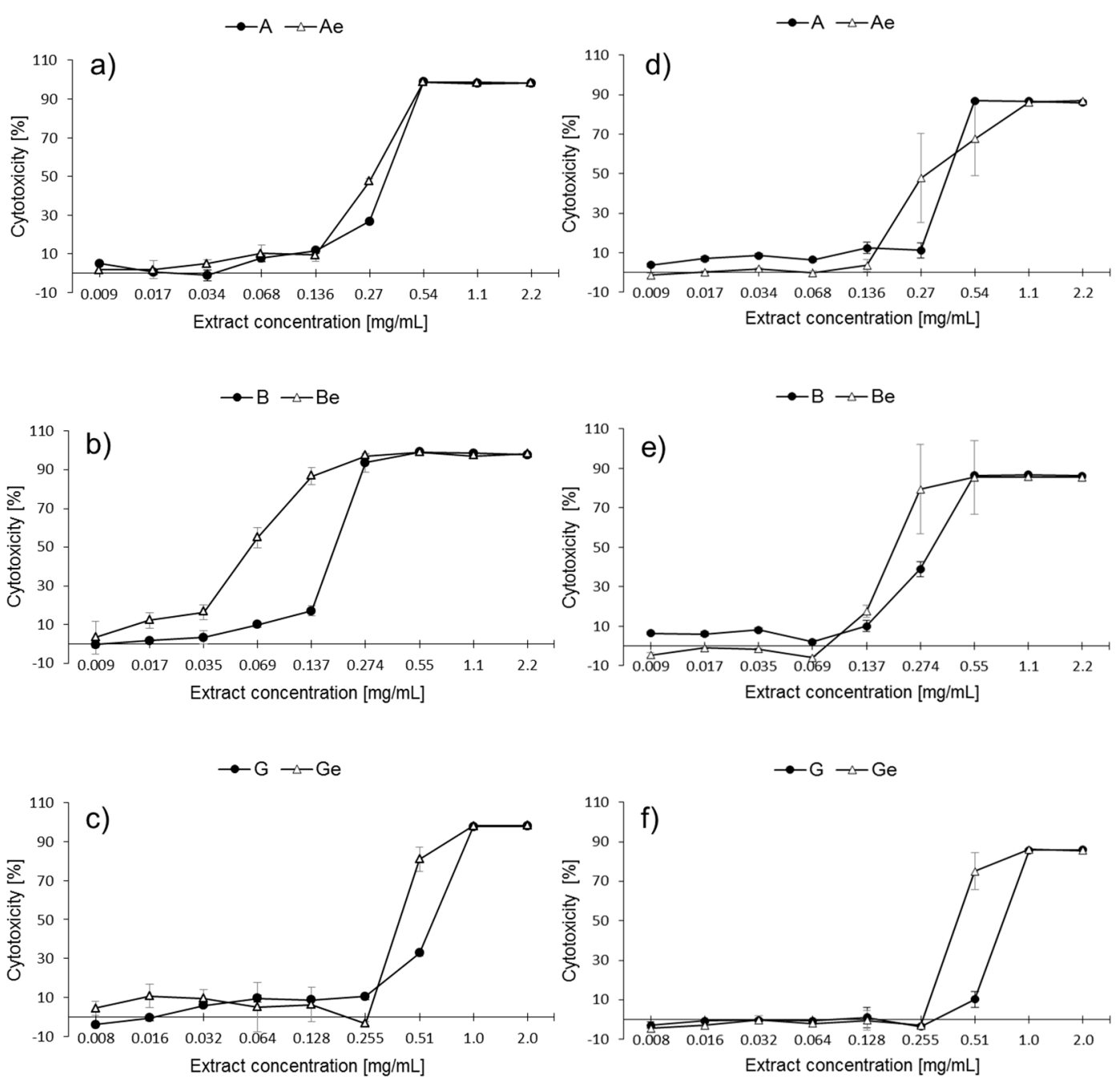

Figure 2. Cytotoxic activity of the P. quinquefolium extracts towards Caco-2 cells determined by MTT (a, b, c graphs) and PrestoBlue (d, e, f graphs) assays after $72 \mathrm{~h}$ of exposure. Each value represents the mean of four repeats $\pm \mathrm{SD}$. Letter $e$ in italic indicates extract of plant subjected to elicitation.

\subsection{Estimation of Half Maximal Inhibitory Concentration $\left(I C_{50}\right)$}

$\mathrm{IC}_{50}$ is defined as the concentration of a compound which is required to reduce cell survival to $50 \%$ of the control values. The $\mathrm{IC}_{50}$ values of all the P. quinquefolium extracts were determined on the basis of MTT and PB assays (Table 2). The $\mathrm{IC}_{50}$ value for each extract, calculated based on the results obtained by the MTT and PB assays, were similar. The highest cytotoxic effect was documented for extract $\mathrm{Be}$ (0.06 in MTT and $0.21 \mathrm{mg} / \mathrm{mL}$ for PB). The least cytotoxic appeared to be extract $\mathrm{G}$, reaching an $\mathrm{IC}_{50}$ of $0.64 \mathrm{mg} / \mathrm{mL}$ (in MTT) and $0.77 \mathrm{mg} / \mathrm{mL}$ (in $\mathrm{PB}$ ). According to the $\mathrm{IC}_{50}$ values, the cytotoxicity of the Panax extracts ranked as follows: Be and B > Ae and A > Ge and G. The extracts obtained by elicitation demonstrated lower $\mathrm{IC}_{50}$ values than those that were not, indicating that the elicited P. quinquefolium plants demonstrate a higher cytotoxic activity. The Presto Blue and MTT assay results indicate comparable patterns of cytotoxicity. The higher sensitivity indicated by the MTT assay may result from the fact that it induces mitochondrial dysfunction, thus augmenting the effect of the extract [24]. 
Table 2. The $\mathrm{IC}_{50}$ values of the P. quinquefolium extracts determined in MTT and PrestoBlue assays. Letter $e$ in italic indicates extract of plant subjected to elicitation.

\begin{tabular}{ccc}
\hline \multirow{2}{*}{ Extract } & \multicolumn{2}{c}{ IC $_{50}[\mathrm{mg} / \mathrm{mL}]$} \\
\cline { 2 - 3 } & MTT & PrestoBlue \\
\hline $\mathrm{A}$ & 0.35 & 0.40 \\
\hline $\mathrm{A} e$ & 0.29 & 0.31 \\
\hline $\mathrm{B}$ & 0.19 & 0.33 \\
\hline $\mathrm{B} e$ & 0.06 & 0.21 \\
\hline $\mathrm{G}$ & 0.64 & 0.77 \\
\hline $\mathrm{G} e$ & 0.42 & 0.43 \\
\hline
\end{tabular}

In general, our findings indicate that the P. quinquefolium hairy root extracts derived from the cultures that underwent MeJA elicitation had stronger cytotoxic properties. The analysis of the $\mathrm{IC}_{50}$ values showed that these parameters are lower for the Ae, Be and Ge clones than for the A, B and G clones, respectively. This would suggest that higher saponin levels are associated with a stronger cytotoxic activity against Caco-2 cells. However, in contrast, extracts B and Be were the most cytotoxic, even though they contained the lowest level of ginsenosides. This is strong evidence that the observed biological activity relies on the chemical composition rather than the total quantity of the compounds: the two extracts were the richest sources of $\mathrm{Rc}, \mathrm{Rb} 1$ and $\mathrm{Rg} 1$ ginsenosides. In addition, these findings might be attributed to the presence of rare ginsenosides such as Rh2, Rh3, Rg2 or Rg5, which were not studied in the present study. The literature data indicated that these metabolites demonstrate cytotoxic, anti-cancer and anti-proliferative activities; however, they also appear in greater quantities after subjecting field-cultivated roots to high temperatures [25-29].

A previous study [30] examined the anti-proliferative activity of P. quinquefolium extracts towards HCT-116 colorectal cancer cells by the modified trichrome stain (MTS) method. Higher concentrations of the extracts were found to be associated with lowered cell viability. At lower concentrations $(0.1-0.25 \mathrm{mg} / \mathrm{mL})$, the anti-proliferative activity was minimal, while a significantly higher (above $90 \%$ ) activity was observed for the higher concentrations $(0.5 \mathrm{mg} / \mathrm{mL})$ [30]. In our case, the pattern of results was similar.

A previous MTT-based study of the cytotoxicity of a P. quinquefolium extract towards hepatocellular carcinoma cells (SMMC-7721) also found that the survival rate of cells decreased along with the increase in the extract concentration. The cells were incubated with different extract concentrations $(0,20,40,60$ and $80 \mathrm{mg} / \mathrm{mL}$ ) for $12 \mathrm{~h}$. [31]. The Rg3 ginsenoside level was also found to significantly decrease 375.S2 melanoma cell viability compared with controls $\left(\mathrm{IC}_{50} 20 \mu \mathrm{M}\right)$ [32]. Li et al. [33] observed that the total ginsenoside extract of Chinese ginseng containing a mixture of $\mathrm{Rg} 1, \mathrm{Re}, \mathrm{Rd}$ and $\mathrm{Rb} 1$ induced stronger cytotoxicity against HT-29 human colon cancer cells than its individual ginsenoside components. After a $72-\mathrm{h}$ treatment, the $\mathrm{IC}_{50}$ was equal to $0.105 \mathrm{mg} / \mathrm{mL}$.

\subsection{Basal Endogenous DNA Damage Induced by P. quinquefolium Extracts}

The genotoxicity of the different concentrations of the P. quinquefolium extracts was estimated by means of a comet assay. The mean percentage of DNA in the comet tail \pm S.E.M. at the different concentrations of the extract is given in Table 3 . The choice of concentrations was based on the $\mathrm{IC}_{50}$ data analysis (close or lower than $\mathrm{IC}_{50}$ ).

Negative control cells demonstrated $4.2 \% \pm 0.3 \%$ DNA damage, while the positive controls demonstrated $40.6 \% \pm 3.6 \%$. The genotoxic activity of extracts was observed to be dose-dependent. The highest concentrations of the P. quinquefolium extracts were noticed to be the most genotoxic. The lowest extract concentrations displayed a slightly higher genotoxic activity than the medium ones. Extracts A and Ae at concentrations 0.017 and $0.068 \mathrm{mg} / \mathrm{mL}$ induced comparable results in 
DNA damage, i.e., up to $10.2 \% \pm 0.6 \%$. At a concentration of $0.27 \mathrm{mg} / \mathrm{mL}$, extract A was found to be 2.5-times more genotoxic than Ae, resulting in $63.5 \% \pm 1.9 \%$ DNA damage compared with $25.6 \% \pm$ $2.3 \%$. Extracts B and Be demonstrated similar genotoxicity at concentrations of 0.009 and $0.035 \mathrm{mg} / \mathrm{mL}$. Extract $\mathrm{B} e$ seemed to display stronger genotoxic effects at a concentration of $0.137 \mathrm{mg} / \mathrm{mL}(40.9 \% \pm$ $2.4 \%)$ than extract B $(34.0 \% \pm 3.3 \%)$. At a concentration of $0.51 \mathrm{mg} / \mathrm{mL}$, extract $\mathrm{G}$ demonstrated $66.6 \%$ $\pm 1.8 \%$ genotoxicity, while at $0.255 \mathrm{mg} / \mathrm{mL} \mathrm{Ge}$ exerted $41.6 \% \pm 2.7 \%$ genotoxicity. Extract Ge was probably more genotoxic than $\mathrm{G}$, indicated by the fact that half the concentration was needed to induce similar genotoxic effects to $G$. Those values cannot be exactly compared due to the different tested concentrations (chosen on the basis of the $\mathrm{IC}_{50}$ values).

Table 3. DNA damage in Caco-2 cells exposed to the P. quinquefolium extracts expressed as the mean DNA content in the tail of comets ( \pm S.E.M.) in the alkaline comet assay. The number of cells analyzed was equal to 100. Different letters (a-r) indicate significant differences between results, ANOVA $(p<0.05)$. Letter $e$ in italic indicates extract of plant subjected to elicitation.

\begin{tabular}{|c|c|c|}
\hline Extract & Concentration $[\mathrm{mg} / \mathrm{mL}]$ & DNA in the Tail $[\%] \pm$ S.E.M. \\
\hline \multirow{3}{*}{ A } & 0.017 & $10.2 \pm 0.6^{\mathrm{a}, \mathrm{b}}$ \\
\hline & 0.068 & $6.6 \pm 1.1^{\mathrm{a}, \mathrm{c}}$ \\
\hline & 0.270 & $63.5 \pm 1.9^{b, c}$ \\
\hline \multirow{3}{*}{$\mathrm{A} e$} & 0.017 & $8.1 \pm 1.4^{j}$ \\
\hline & 0.068 & $9.5 \pm 1.5^{k}$ \\
\hline & 0.270 & $25.6 \pm 2.3^{\mathrm{j}, \mathrm{k}}$ \\
\hline \multirow{3}{*}{ B } & 0.009 & $10.2 \pm 0.7^{\mathrm{e}, \mathrm{f}}$ \\
\hline & 0.035 & $7.6 \pm 1.1^{\mathrm{e}, \mathrm{g}}$ \\
\hline & 0.137 & $34.0 \pm 3.3^{f, g}$ \\
\hline \multirow{3}{*}{$\mathrm{B} e$} & 0.009 & $9.9 \pm 0.6^{1, m}$ \\
\hline & 0.035 & $7.6 \pm 0.8^{1, n}$ \\
\hline & 0.137 & $40.9 \pm 2.4^{\mathrm{m}}$ \\
\hline \multirow{3}{*}{ G } & 0.032 & $7.6 \pm 0.7^{h}$ \\
\hline & 0.128 & $8.5 \pm 1.7^{\mathrm{i}}$ \\
\hline & 0.510 & $66.6 \pm 1.8^{h, i}$ \\
\hline \multirow{3}{*}{$\mathrm{Ge}$} & 0.016 & $12.1 \pm 0.7^{\mathrm{o}, \mathrm{q}}$ \\
\hline & 0.064 & $8.4 \pm 1.3^{\mathrm{o}, \mathrm{r}}$ \\
\hline & 0.255 & $41.6 \pm 2.7^{\mathrm{q}, \mathrm{r}}$ \\
\hline
\end{tabular}

No correlation was found between genotoxic effects and the source plant species. There is no data on the genotoxicity of P. quinquefolium extracts on cell lines, but Zhang et al. [34] found Rg3 ginsenoside to significantly increase DNA damage in a concentration-dependent manner in human osteosarcoma cells. Rg3 also induced double-strand breaks, which can lead to chromosome aberrations.

\subsection{Effect of P. quinquefolium Extracts on Colony Formation}

Extracts $\mathrm{B}$ and $\mathrm{B} e$ displayed the strongest cytotoxic and anti-proliferative effects and so were subjected to further research based on a colony forming assay: the survival and proliferative capacity of cells treated with a cytotoxic agent are measured based on their ability to form colonies. It was found that the pre-treatment of cells with Panax B and Be extracts effectively inhibited the colony formation (Figure 3), which was clearly visible in the samples containing extracts of concentrations equal to and higher than $0.55 \mathrm{mg} / \mathrm{mL}$. These findings confirm that extracts were not only able to decrease the metabolic activity of Caco- 2 cells but also had an anti-proliferative effect. An analysis of the colony formation ability of melanoma A375.S2 cells $24 \mathrm{~h}$ after treatment with different Rg3 ginsenoside concentrations found this ability to decrease for all $\mathrm{Rg} 3$ concentration levels compared with controls [32]. 

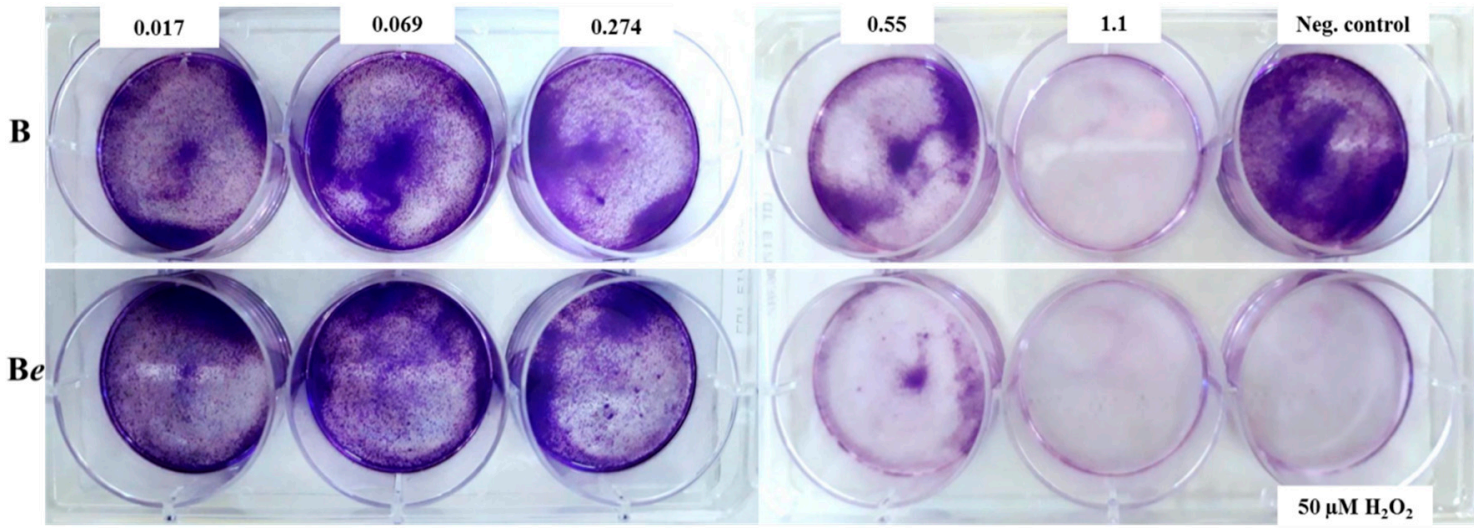

Figure 3. Images representing colonies produced by Caco-2 cells following plating of 1000 cells and 7 days of incubation. Cells were treated with $0.017-1.1 \mathrm{mg} / \mathrm{mL}$ concentrations of the P. quinquefolium $\mathrm{B}$ (non-elicited) and $\mathrm{B} e$ (elicited) extracts for $60 \mathrm{~min}$. A positive control in a form of $50 \mu \mathrm{M} \mathrm{H}_{2} \mathrm{O}_{2}$ was used. Cells in negative control were not treated. Letter $e$ in italic indicates extract of plant subjected to elicitation.

2.6. The Effect of P. quinquefolium Extracts on Intracellular ATP Level, Mitochondrial Membrane Potential, Intracellular Oxidative Stress and Apoptosis Induction

Further analyses at concentrations not exceeding the $\mathrm{IC}_{50}$ values were performed to determine the molecular mechanism of the $\mathrm{B}$ and $\mathrm{B} e$ ginsenosides' cytotoxicity against Caco-2 cells. It was found that both extracts influenced cellular ATP production (Figure 4A). The ATP level in Caco-2 cells decreased by $20 \%$ following the treatment with $0.137 \mathrm{mg} / \mathrm{mL}$ extract of the plant following elicitation; this decreased to $50 \%$ at the higher concentration of $0.274 \mathrm{mg} / \mathrm{mL}$. Ginseng B preparation reduced luminescence by $10-15 \%$ at all studied dosages.

Both extracts reduced the mitochondrial membrane potential in a concentration-dependent manner (Figure 4B). While extract B diminished the potential by up to $15 \%$, extract Be reduced the value by $20 \%$ to $60 \%$. This observed decrease in the mitochondrial potential was accompanied by an intracellular increase in the ROS level for both B and Be (Figure 4C); however, $0.137 \mathrm{mg} / \mathrm{mL}$ extract B was a stronger inducer of oxidative stress: it elevated fluorescence by nearly $20 \%$ compared to controls, whereas $0.274 \mathrm{mg} / \mathrm{mL}$ Be extract increased the ROS level by nearly $45 \%$. These quantitative results were confirmed by fluorescence microscopy observations: cells treated with extracts $\mathrm{B}$ and $\mathrm{B} e$ demonstrated higher fluorescence than untreated cells due to the higher ROS concentration (Figure 5). Extract Be demonstrated a stronger intracellular ROS accumulation. 
A

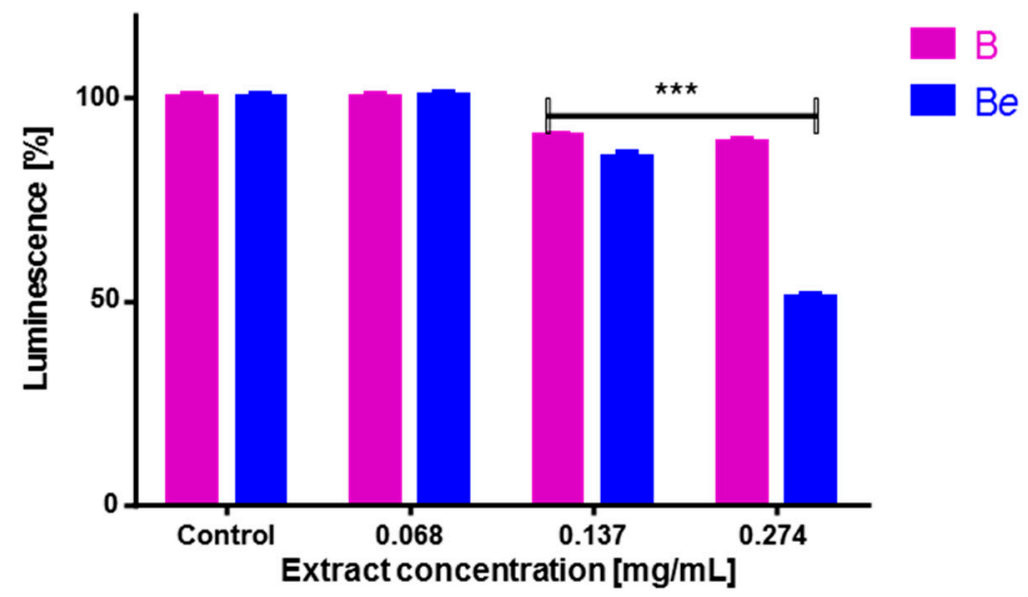

B

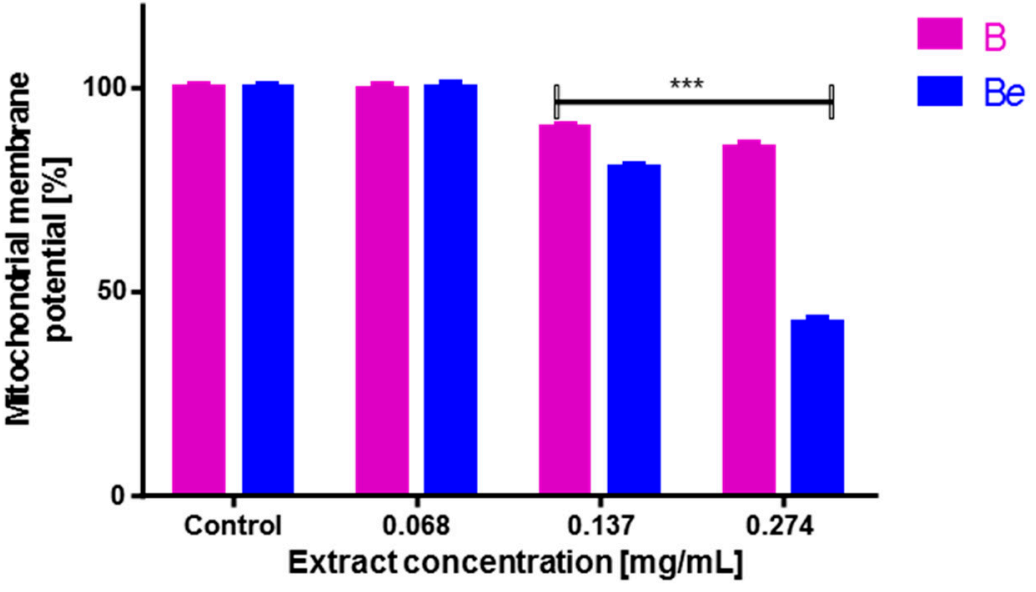

C

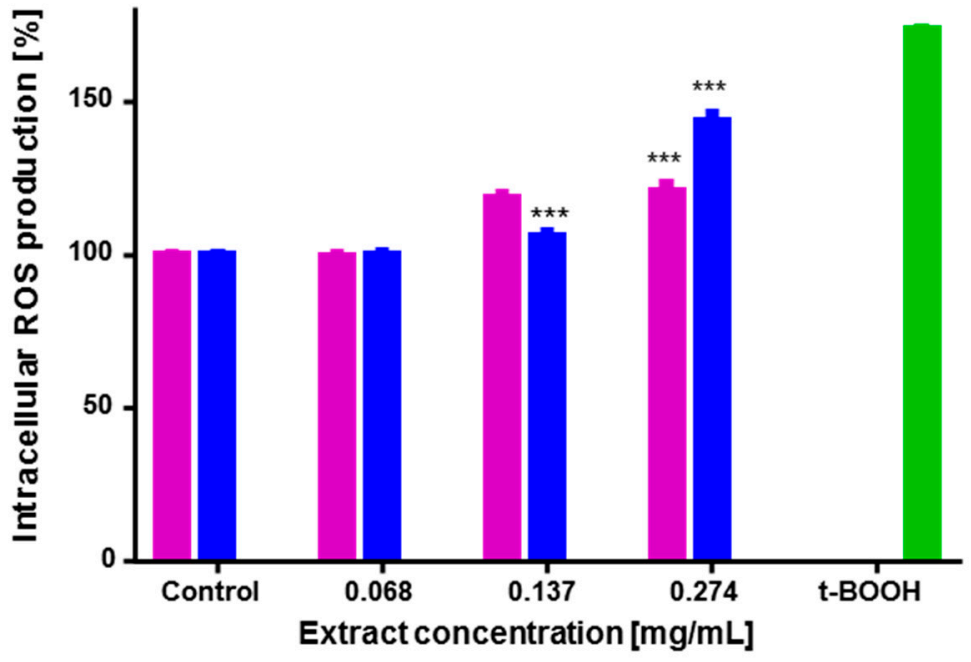

Figure 4. The effects of the 48-h P. quinquefolium B (non-elicited) and Be (elicited) extract treatment on the ATP level of Caco-2 cells as determined by the ATP luminescent assay kit (A); mitochondrial membrane potential was determined with a JC-1 probe (B); intracellular reactive oxygen species (ROS) generation was analyzed by a DCFH-DA assay (C), as a positive control of $50 \mu \mathrm{M} t$-BOOH was used; control cells were not exposed to any compound but the vehicle (medium). Values are presented as the mean $(n \geq 8) \pm S D$; statistical significance was calculated versus the control cells (untreated), $* * * p<0.001$. 

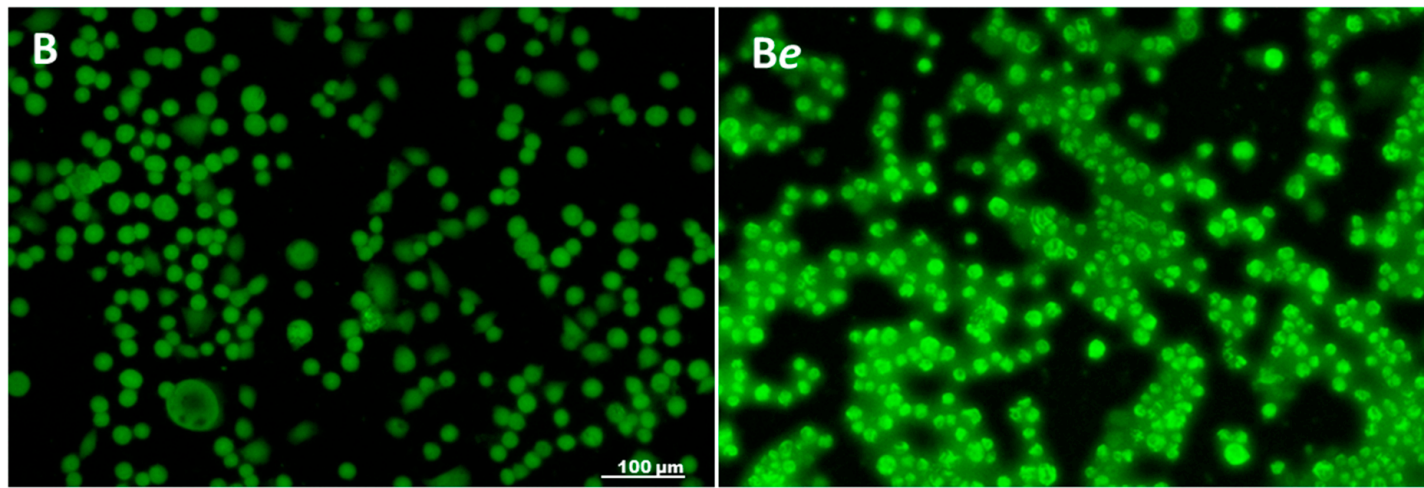

\section{Negative control}

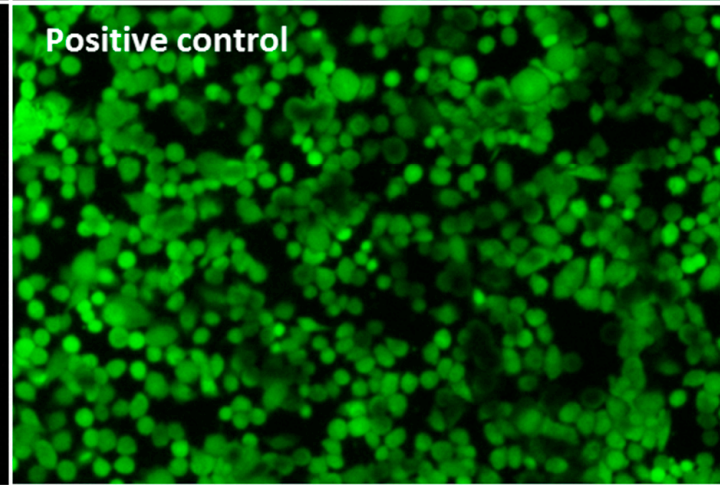

Figure 5. Intracellular ROS generated in Caco-2 cells after staining with DCFH-DA. The P. quinquefolium extract $(0.274 \mathrm{mg} / \mathrm{mL}) \mathrm{B}$ non-subjected to elicitation (with lower fluorescence) and Be subjected to elicitation (with higher fluorescence). Negative control—healthy cells without fluorescence (no ROS). Positive control (50 $\mu \mathrm{M} t$-BOOH) with highly fluorescent cells. Fluorescence microscopy (Nikon, Tokyo, Japan), 200× magnification.

The observed decrease in the mitochondrial potential and ATP level, as well as the intensive elevation of ROS, indicated that cellular death may be triggered, like apoptosis or necrosis. Therefore, the next part of the study investigated the impact of the ginseng extracts on apoptosis induction by the detection of externalized phosphatidylserine (PS) in the cell membrane using annexin-V-FITC/propidium iodide staining (Figure 6A). Annexin V binds to externalised phosphatidylserine on the outer membrane leaflet of apoptotic cells, whilst the propidium iodide stains the nuclei of cells with perforated membranes. The highest number of apoptotic cells positive for annexin V staining was observed for $0.137 \mathrm{mg} / \mathrm{mL}$ of ginseng B (about $18 \%$ ), whereas high levels of cells positive for both annexin $\mathrm{V}$ and propidium iodide were observed for the Be extract at $0.137 \mathrm{mg} / \mathrm{mL}$ and the $B$ extract at $0.274 \mathrm{mg} / \mathrm{mL}$. Ginseng $B e$ at a $0.274 \mathrm{mg} / \mathrm{mL}$ concentration revealed a high red fluorescence quantity of cells with stained nuclei (about $58 \%$ ) specific for necrosis or secondary necrosis of apoptotic bodies not engulfed by neighbouring cells. A subsequent DNA fragmentation analysis of the cytoplasmic mono- and oligonucleosomes revealed a significant increase in apoptosis induction by the $\mathrm{B}$ and $\mathrm{Be}$ extracts at $0.137 \mathrm{mg} / \mathrm{mL}$ (Figure $6 \mathrm{~B}$ ). Further investigation showed that cells treated with a $0.274 \mathrm{mg} / \mathrm{mL}$ concentration of both preparations showed predominantly necrotic death-type features due to the presence of cell-released nucleosomes in the culture medium. 
A

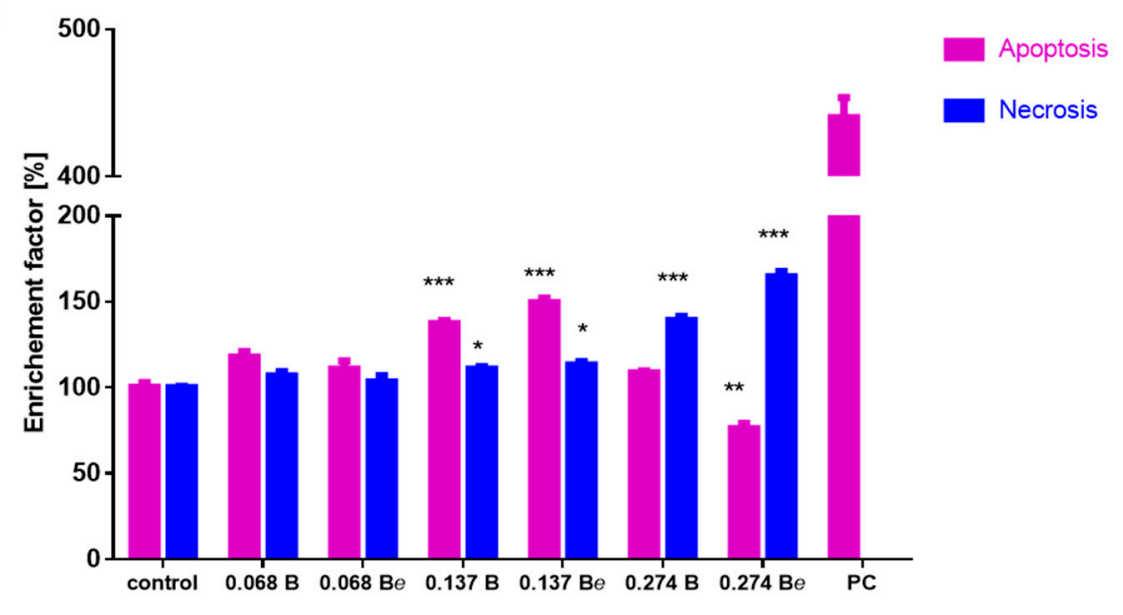

B

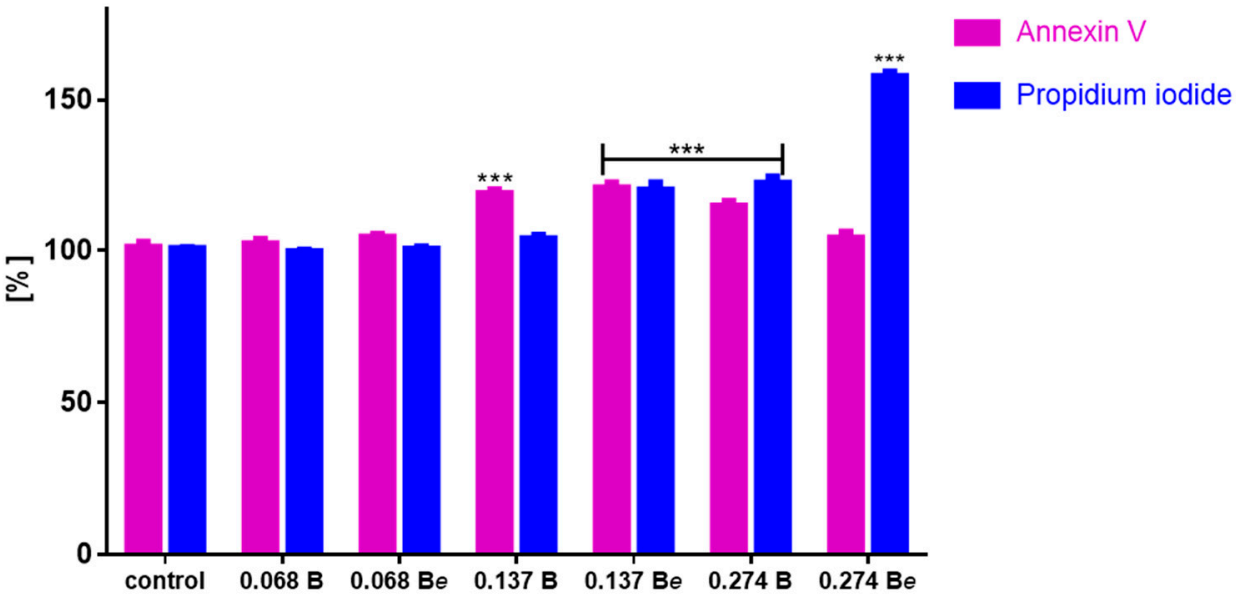

Figure 6. The effects of the P. quinquefolium B (non-elicited) and Be (elicited) extracts after $48 \mathrm{~h}$ treatment of Caco-2 cells: phosphatidylserine externalisation on the outer membrane leaflet of the apoptotic cells and membrane permeabilization were detected with the annexin-V-FITC assay kit and propidium iodide staining (A); the late stage of apoptosis was analyzed by a cell death detection kit (B), PC - internal positive control of the assay. Control cells were not exposed to any compound but the vehicle (medium). Values are presented as the mean $(n \geq 8) \pm S D$; statistical significance was calculated versus the control cells (untreated), ${ }^{*} p<0.05,{ }^{* *} p<0.01,{ }^{* * *} p<0.001$.

The current results are consistent with the microscopic observations of the cellular morphology changes occurring after cellular death induction. DAPI staining allows morphological changes in cell nuclei to be assessed. The nuclear morphology of Caco- 2 cells was evaluated after $48 \mathrm{~h}$ of exposure to $0.137 \mathrm{mg} / \mathrm{mL}$ of the B and Be extracts. Numerous apoptotic bodies, chromatin condensation and nuclear fragmentation could be observed (Figure 7). AO/PI staining analyses were also conducted according to the criteria given by Baskić et al., 2006 [35] and Salim et al., 2013 [36]. The control cells (viable) exhibited a green fluorescence with a light-green nucleus with an intact structure of the chromatin (Figure 8). An orange colour, chromatin fragmentation, cell shrinkage and cell membrane blebbing were symptoms of late apoptosis, while bright-red nuclei with condensed chromatin indicated direct necrosis. Kim et al., 2019 [32] demonstrated that the Rg3 ginsenoside induced apoptosis in A375.S2 melanoma cells related to the mitogen-activated protein kinase signalling pathway. The authors also observed morphological changes in cells such as membrane blebbing. Li et al., 2018 [33], in DAPI staining, observed nuclear changes in the colon cancer cell HT-29 typical for apoptosis, such as karyopyknosis, chromatin condensation and nuclear fragmentation. These observations were made for the total ginsenosides of Chinese ginseng containing Rg1, Re, Rd and Rb1. 

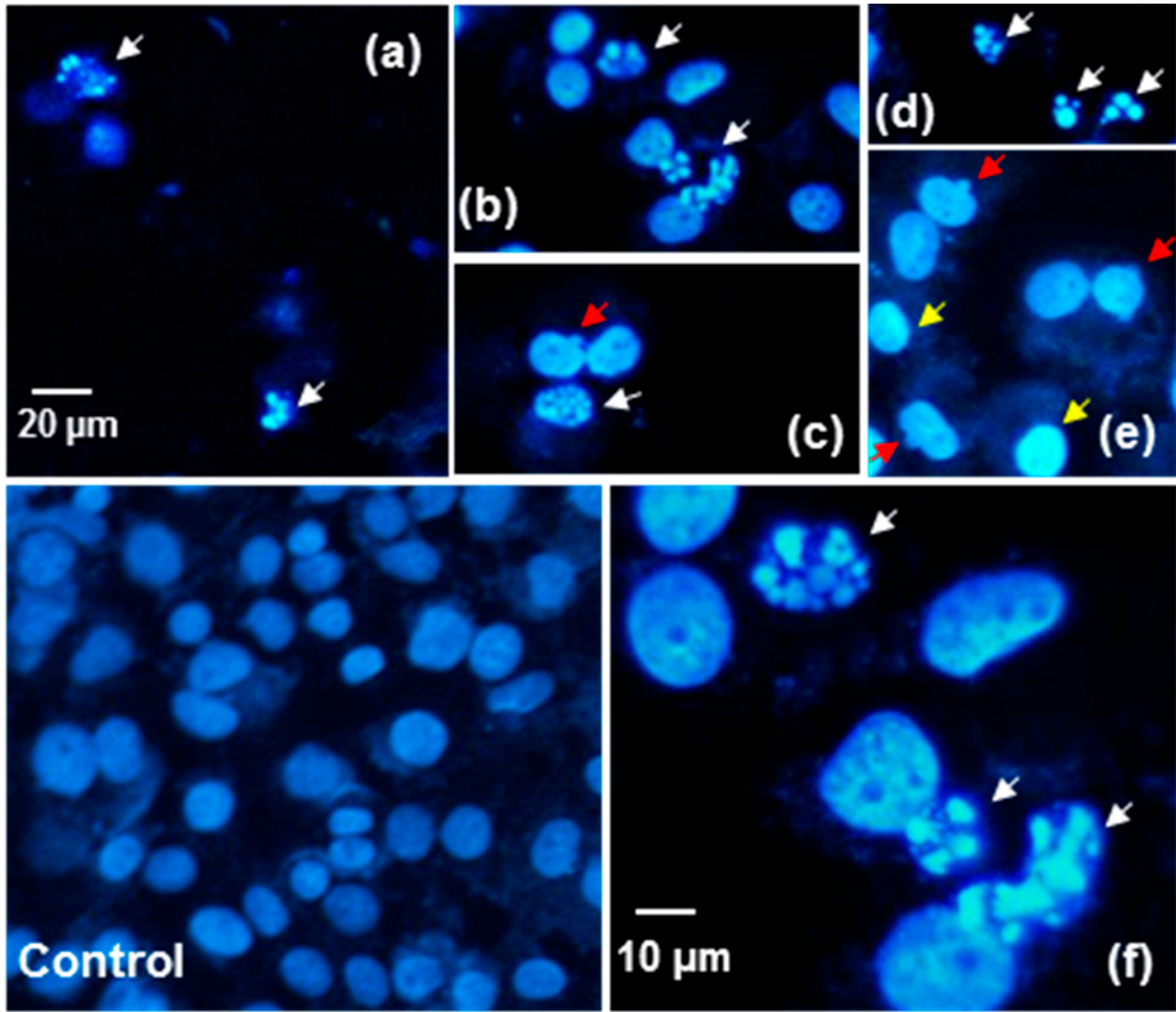

Figure 7. DAPI-stained nuclei of Caco-2 cells after exposition to $0.137 \mathrm{mg} / \mathrm{mL}$ of the P. quinquefolium extracts B (non-elicited) $(\mathbf{a}-\mathbf{c})$ and $\mathrm{B} e$ (elicited) $(\mathbf{e}-\mathbf{f})$. Apoptotic bodies (white arrows), chromatin condensation (yellow arrows) and nuclear fragmentation (red arrows). Magnifications 200× (control, a-e) and 400× (f, and magnified $\mathbf{b})$.
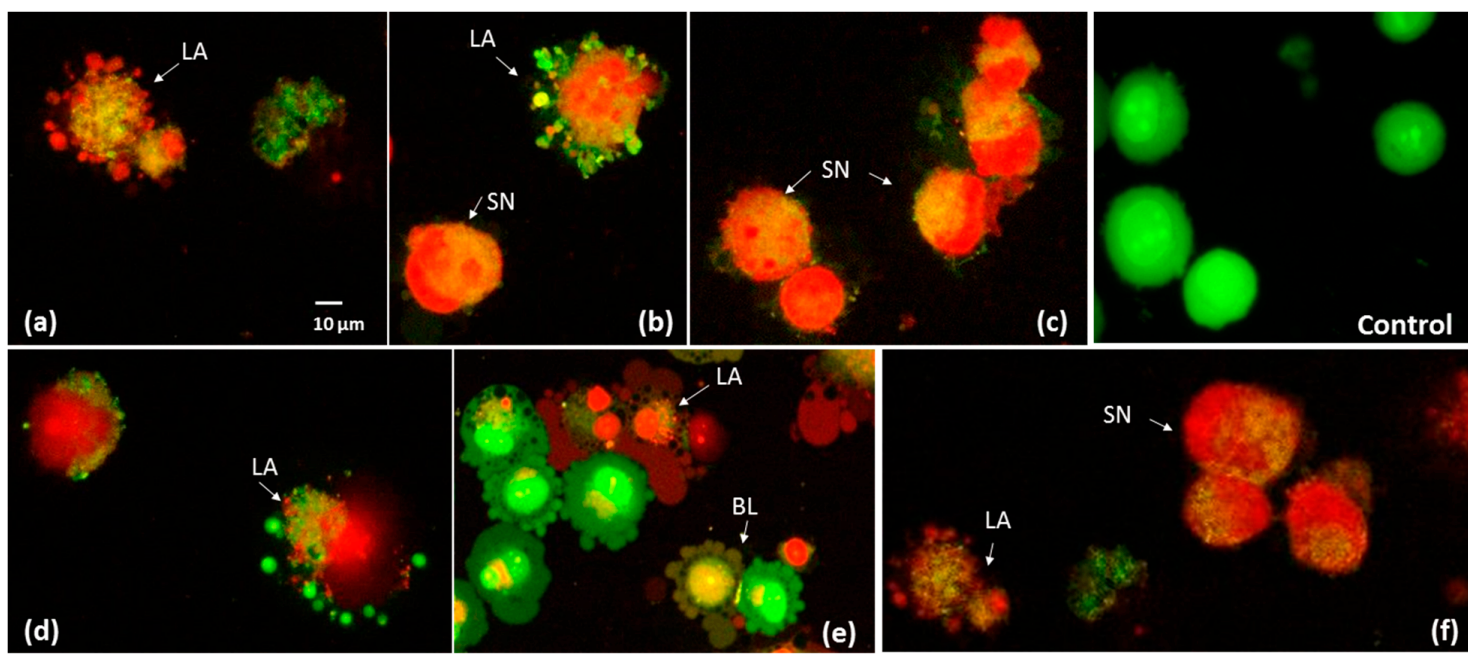

Figure 8. Fluorescent images of AO/PI double staining of Caco-2 cells exposed to $0.137 \mathrm{mg} / \mathrm{mL}(\mathbf{a}, \mathbf{b}, \mathbf{d}, \mathbf{e})$ and $0.274 \mathrm{mg} / \mathrm{mL}(\mathbf{c}, \mathbf{f})$ of the P. quinquefolium extracts B (non-elicited) $(\mathbf{a}-\mathbf{c})$ and Be (elicited) $(\mathbf{d}-\mathbf{f})$. LA-late apoptosis, BL—blebbing, $\mathrm{SN}$-secondary necrosis. $400 \times$ magnification.

There are many reports indicating that $\mathrm{Rg} 3, \mathrm{Rh} 2, \mathrm{Rg} 5, \mathrm{Rk} 1$ and $\mathrm{Rh} 4$ ginsenosides act as apoptosis inducers in different types of cell lines [37-39]. It is supposed that the most potent apoptosis activators among saponins are those with less polar chemical structures [40]. Recently, it was demonstrated that not only ginsenosides but also their metabolites secreted by intestinal bacteria, like compound K, 
are able to activate apoptosis via the induction of intracellular reactive oxygen species and mitochondria membrane potential loss [41]. Remarkably, apoptosis as a programmed cell death (implicated in the removal of defective or unwanted cells without inflammation induction) is one of the tools used in cancer prevention. Studies performed on a BALB/c nude mouse model of human breast cancer demonstrated that $\operatorname{Rg} 5$ activates caspase-dependent apoptosis via the activation of the extrinsic death receptor and intrinsic mitochondrial signalling pathways [42]. We examined the ginsenoside involvement in Caco-2 cell death induction via oxidative stress generation; however, a more detailed evaluation of specific markers connected with cellular death, such as caspases $-3 /-9$ activation or the appearance of specific proteins, i.e., t-Bid, cytochrome c, Bax and Bak, is required [40]. Such a molecular identification is very important because in human colorectal cancer HCT116 cells, there have been demonstrated studies identifying ginsenosides $\mathrm{Rh} 2$ and $\mathrm{Rg} 3$ as not only inducers of apoptotic-type cellular death but also as activators of paraptosis [43]. That type of cell death is independent of caspase activation and is characterized by cytoplasmic vacuole formation, mitochondrial swelling and clumping.

The present study also examines the ability of the extracts to induce necrosis. However, it is important to mention that some proteins involved in the intrinsically regulated type of cell death, which shares features of apoptosis and necrosis, are responsible for the induction of the cellular death type known as necroptosis [44]. On the other hand, the treatment of H9c2 cardiomyocytes with the deglycosylated ginsenoside compound Mc1 significantly increased the levels of catalase and superoxide dismutase and reduced the elevation of the proapoptotic Bax/Bcl2 ratio and caspase- 3 activity [45]. Due to these facts, the identification of the detailed mechanism of the biological activity of $P$. quinquefolium ginsenosides requires further investigation.

\section{Materials and Methods}

\subsection{Chemicals and Reagents}

The N-2-hydroxyethylpiperazine- $N^{\prime}$-2-ethanesulfonic acid (HEPES) buffer, Dulbecco's modified Eagle's medium (DMEM), streptomycin/penicillin mixture, phosphate buffered saline (PBS, pH 7.2), trypan blue dye, 3-(4,5-dimethylthiazol-2-yl)-2,5-diphenyltetrazolium bromide (MTT), dimethyl sulfoxide (DMSO), low melting point (LMP) agarose, normal melting point (NMP) agarose, $\mathrm{NaCl}$, Triton X-100, EDTA, Tris, NaOH, paraformaldehyde, 4,6-diamidino-2-phenylindole (DAPI), acridine orange (AO), propidium iodide (PI), 2' $7^{\prime}$-dichlorofluorescin diacetate (DCFH-DA), hydrogen peroxide $\left(\mathrm{H}_{2} \mathrm{O}_{2}\right)$, annexin-V-FITC assay kit, tert-butyl hydroperoxide $(t-\mathrm{BOOH})$, and methyl jasmonate (MeJA) were derived from Sigma-Aldrich (St. Louis, MO, USA). The Rb1, Rb2, Rb3, Rc, Rd, $\mathrm{Re}, \mathrm{Rg} 1$ and Rg2 ginsenosides standards were purchased from C. Roth $\mathrm{GmbH}+\mathrm{Co}$ Karlsruhe, Germany. The foetal bovine serum (FBS), GlutaMAX ${ }^{\mathrm{TM}}$, TrypLE ${ }^{\mathrm{TM}}$ Express, PrestoBlue (PB), 5,5',6,6'-tetrachloro-1, 1' ,3,3'-tetraethyl-imidacarbocyanine iodide (JC-1) originated from Invitrogen Thermo Fisher Scientific (Waltham, MA, USA). The human colon adenocarcinoma cell line Caco-2 from the $50^{\text {th }}$ passage was purchased from Cell Line Service GmbH (Eppelheim, Germany). The 0.20 and $0.22 \mu \mathrm{m}$ pore size syringe filters were from Merck Millipore (Darmstadt, Germany). The Cell Death Detection ELISA ${ }^{\text {Plus }}$ was purchased from Roche Diagnostics (Basel, Switzerland). The CellTiter-Glo ${ }^{\circledR}$ Luminescent Cell Viability Assay kit was from Promega (Madison, WI, USA).

\subsection{P. quinquefolium Hairy Root Culture}

Three clones (A, B and G) of the P. quinquefolium hairy root cultures were grown in $300 \mathrm{~mL}$ shake Erlenmeyer flasks with $80 \mathrm{~mL}$ of modified, hormone-free B-5 medium [14]. The cultures were maintained in the dark at $26^{\circ} \mathrm{C}$ degrees on a rotary shaker $(100 \mathrm{rpm})$. The extracts were prepared from three different clones of the transformed roots of $P$. quinquefolium and were used for the biological assays. They were derived from cultures that did not undergo an elicitation process (A, B and G) and from the hairy roots that were elicited by the $250 \mu \mathrm{M}$ MeJA (Ae, Be and Ge). A stock solution containing 
95\% MeJA in $96 \%$ ethanol (sterilized through a Millipore filter of pore size $0.20 \mu \mathrm{m}$ ) was added to the medium on the 25th day of culture. The ginseng saponins accumulation in the hairy root cultures of P. quinquefolium was examined after seven days of the MeJA treatment.

\subsection{Preparation of P. quinquefolium Roots' Extracts}

The hairy root cultures, after 32 days of growth in in vitro conditions, were rinsed under running water to remove medium residue, dried at room temperature and subjected to extraction in $80 \%$ methanol and solid phase extraction, as described earlier [14]. The dried hydromethanolic extracts, taken from all the tested cultures, were weighed and used for the quantitative analysis of the ginsenosides (HPLC method). For further investigations of the biological activity towards Caco-2 cells, the stock solutions were prepared after dissolving in a complete culture medium for Caco-2 cells (without phenol red). They were sterile-filtered $(0.22 \mu \mathrm{m}$ pore size) and diluted to the $10 \times$ stock concentrations from 0.08 to $22 \mathrm{mg} / \mathrm{mL}$. The stocks were stored at $-20{ }^{\circ} \mathrm{C}$.

\subsection{Determination of Ginsenoside Content Using HPLC Method}

The samples were examined for the presence of eight ginsenosides ( $R b 1, R b 2, R b 3, R c, R d, R e, \operatorname{Rg} 1$ and Rg2) using a liquid chromatography system consisting of an Agilent Technology 1200 apparatus, a ZORBAX Eclipse XDB-C18 $(150 \times 4.6 \mathrm{~mm}, 5 \mu \mathrm{m})$ column, Quat Pump and UV-Vis DAD type detector, as well as an Agilent Technology set combined with the Agilent ChemStation 2001-2010 software. The details of this analysis are presented in our earlier report [46]. The ginsenoside content was expressed as milligrams per gram of dry weight.

\subsection{Caco-2 Cell Culture}

Caco-2 cells were maintained according to Nowak et al., 2017 [47]. They were cultured in DMEM, supplemented with 10\% FBS, 4 mM GlutaMAX ${ }^{\mathrm{TM}}, 25 \mathrm{mM}$ HEPES buffer and $100 \mu \mathrm{g} / \mathrm{mL}$ streptomycin $/ 100 \mathrm{IU} / \mathrm{mL}$ penicillin mixture for 7 days at $37^{\circ} \mathrm{C}$ in the atmosphere of $5 \% \mathrm{CO}_{2}$. Every 2-3 days, the cells were washed with PBS and supplemented with a fresh medium. Confluent cells were detached with TrypLE ${ }^{\mathrm{TM}}$ Express. The cell suspension was centrifuged (182× $\left.g, 5 \mathrm{~min}\right)$, decanted and the pellet was re-suspended in fresh DMEM. After the determination of the cell count by haemocytometer and cell viability by trypan blue exclusion, the Caco-2 cells were ready to use.

\subsection{MTT and PB Assays}

In each well of a 96-well plate, $1 \times 10^{4} \mathrm{Caco}-2$ cells were seeded in a complete culture medium and incubated overnight $\left(37^{\circ} \mathrm{C}, 5 \% \mathrm{CO}_{2}\right)$. Next, the medium was aspirated, and the plant extracts were added to achieve final concentrations of from 0.008 to $2.2 \mathrm{mg} / \mathrm{mL}$. The negative control contained cells in DMEM. Cells were exposed to extracts for $72 \mathrm{~h}\left(37^{\circ} \mathrm{C}, 5 \% \mathrm{CO}_{2}\right)$. After incubation, the samples were aspirated; MTT $(0.5 \mathrm{mg} / \mathrm{mL})$ was added and the samples were further incubated for $3 \mathrm{~h}$. Next, the dye was removed, and formazan precipitates were solubilised by DMSO. Absorbance was measured at $550 \mathrm{~nm}$ (with a reference filter of $620 \mathrm{~nm}$ ) using a microplate reader (TriStar ${ }^{2}$ LB 942, Berthold Technologies GmbH \& Co. KG, Bad Wildbad, Germany).

In the case of the PB assay, after removing the test samples, the PB reagent $(10 \%)$ was added to each well and the samples were incubated at $37^{\circ} \mathrm{C}$ under $5 \% \mathrm{CO}_{2}$ for $2 \mathrm{~h}$. The fluorescence signal at F560/590 $\mathrm{nm}$ was then measured, using a microplate reader. Both experiments were conducted with the same cell's population.

The absorbance/fluorescence of the control sample (untreated cells) represented $100 \%$ cell viability. Cell viability (\%) was calculated as [sample OD (optical density) or fluorescence/control OD or fluorescence] $\times 100 \%$; and anti-proliferative activity/cytotoxicity (\%) as 100-cell viability. Results were presented as the mean \pm standard deviation (SD)/standard error of the mean (S.E.M.). The $\mathrm{IC}_{50}$ value was used as a measure of cellular sensitivity towards a given treatment and was determined by MTT and PB assays according to OECD (The Organisation for Economic Co-operation and Development) 
protocol, 2015 [48], according to the following formula: $\mathrm{IC}_{50}=(\mathrm{X}-\mathrm{Z}) /\left(\mathrm{X}-\mathrm{X}_{1}\right) \times\left(\mathrm{CX}_{1}-\mathrm{CX}\right)+\mathrm{CX}$, where $X$ is a $50 \%$ decrease in viability; $X$ is the $\%$ of viability $>Z ; X_{1}$ is the $\%$ viability $<Z$; $C X$ is the concentration of the compound for $X$, and $\mathrm{CX}_{1}$ is the concentration of the compound for $\mathrm{X}_{1}$.

\subsection{Genotoxicity Testing (Comet Assay)}

The concentrations of the extracts for genotoxicity testing were selected on the basis of the cytotoxicity screening and $\mathrm{IC}_{50}$ values. The cells were incubated $\left(37^{\circ} \mathrm{C}, 1 \mathrm{~h}\right)$ in a supplement-free medium with the following concentrations of the P. quinquefolium extracts $[\mathrm{mg} / \mathrm{mL}]$ : A) $0.017 ; 0.066$ and 0.226; $\mathrm{Ae}$ ) 0.017; 0.069 and 0.275; B) 0.008; 0.034 and 0.135; Be) 0.009; 0.035 and 0.139; G) 0.032; 0.126 and $0.504 ; \mathrm{Ge}) 0.016 ; 0.065$ and 0.258 . The Caco-2 cells' final concentrations were adjusted to $10^{5} \mathrm{cells} / \mathrm{mL}$ in each sample. The negative control consisted of Caco-2 cells in DMEM, while the positive control contained $50 \mu \mathrm{M} \mathrm{H}_{2} \mathrm{O}_{2}$. The final amount of each sample was set to $1 \mathrm{~mL}$. The comet assay was performed under alkaline conditions $(\mathrm{pH}>13)$ as previously described [47]. After incubation, aliquots of suspended cells were centrifuged $\left(182 \times g, 15 \mathrm{~min}, 4^{\circ} \mathrm{C}\right)$, decanted, suspended in $0.75 \%$ LMP agarose and distributed onto slides precoated with 0.5\% NMP agarose and immersed in a lysing solution consisting of $2.5 \mathrm{M} \mathrm{NaCl}, 1 \%$ Triton X-100, $100 \mathrm{mM}$ EDTA and $10 \mathrm{mM}$ Tris, with $\mathrm{pH} 10\left(4^{\circ} \mathrm{C}, 1\right.$ h). After the lysis, the slides were subjected to horizontal gel electrophoresis and the DNA was allowed to unwind for $20 \mathrm{~min}$ in an electrophoretic solution, containing $300 \mathrm{mM} \mathrm{NaOH}$ and $1 \mathrm{mM}$ EDTA. Electrophoresis was conducted at $4{ }^{\circ} \mathrm{C}$ for $30 \mathrm{~min}$ at an electric field of strength $0.73 \mathrm{~V} / \mathrm{cm}(300 \mathrm{~mA})$. Then, the slides were neutralised with distilled water for $5 \mathrm{~min}$, stained with $1 \mathrm{mg} / \mathrm{mL}$ PI and covered with cover slips. The objects were visualised at $200 \times$ total magnification in a fluorescence microscope (Nikon Eclipse Ci H600L, Tokyo, Japan), attached to a digital camera (Nikon Digital Sight DS-U3, Tokyo, Japan) and connected to a Lucia-Comet v. 7.0 PC-based image analysis system (Laboratory Imaging, Prague, Czech Republic). One hundred images were randomly selected from each sample and the percentage of DNA in the comet tail was measured. The results were presented as the mean \pm standard error of the mean (S.E.M.).

\subsection{Clonogenic Assay}

As extracts B and Be appeared to display the strongest cytotoxic and anti-proliferative effects, they were thus taken for further analysis according to Choi et al., 2018 [49], with some modifications. To each well of a 6-well plate, $3.5 \times 10^{5}$ cells were seeded and cultured to reach $80 \%$ confluence. After that, cells were washed with PBS and exposed to extracts of concentrations from 0.017 to $1.1 \mathrm{mg} / \mathrm{mL}$ for $60 \mathrm{~min}$. The positive control was $50 \mu \mathrm{M} \mathrm{H}_{2} \mathrm{O}_{2}$. After that, all cells in each well were harvested, and counted according to the standard procedures. Next, 1000 cells were inoculated on each well of the 6-well plate and cultured for 7 days to enable the formation of the colonies. The colonies were fixed with $3.7 \%$ paraformaldehyde for $15 \mathrm{~min}$, air-dried and stained with $0.1 \%$ crystal violet.

\subsection{Measurement of ATP Production and Mitochondrial Membrane Potential (MMP)}

The intracellular ATP level was quantified with a CellTiter-Glo ${ }^{\circledR}$ Luminescent Cell Viability Assay kit according to the manufacturer's instructions. Briefly, the cells were incubated with the compounds for $48 \mathrm{~h}$, following which, the single reagent was added directly to the cells. After the cell lysis, the luminescence was measured-this was proportional to the amount of ATP present. The measurements were performed using the Synergy 2 BioTek Microplate Reader and calculated according to the formula:

Luminescence $[\%]=$ luminescence of the sample cells/luminescence for the control cells $\times 100$

The MMP was assayed with the JC-1 probe. After $48 \mathrm{~h}$ treatment with the studied compounds, the medium was changed and JC-1 $(1 \mu \mathrm{g} / \mathrm{mL})$ was applied for $20 \mathrm{~min}$. Then, the cells were washed with a serum-free medium and the fluorescent signals at F485/530 and F530/620 nm were measured 
and the ratio of the obtained values F485/530 and F530/620 nm were taken for the calculation according to the formula:

Mitochondrial membrane potential [\%] $=\left(\right.$ ratio of $\mathrm{F}_{530 / 620}$ and $\mathrm{F}_{485 / 530}$ the sample cells/ratio of $\mathrm{F}_{530 / 620}$ and $\mathrm{F}_{485 / 530}$ for the control cells $) \times 100$

\subsection{Detection of Intracellular Reactive Oxygen Species (ROS) Generation}

To determine the effect of extracts on the intracellular generation of ROS after the 48-h treatment, cells were loaded with the DCFH-DA dye at a final concentration of $10 \mu \mathrm{M}$ for $30 \mathrm{~min}$. The fluorescent signal was analyzed at a wavelength of F485/530 $\mathrm{nm}$. Calculations were performed according to the formula:

Intracellular ROS production [\%] = fluorescence of the sample cells/fluorescence of the control cells $\times 100$

For the microscopic observations, the experiment was conducted in 8-well Lab-Tek ${ }^{\mathrm{TM}}$ Chamber Slides. The negative control contained only cells in DMEM (without FBS), while the positive control contained $50 \mu \mathrm{M} t$-BOOH. The intracellular fluorescence of cells was observed under a fluorescence microscope after $6 \mathrm{~h}$ of treatment. An increased intensity of intracellular fluorescence was an indication of an increased level of the generated ROS.

\subsection{Phosphatidylserine Externalisation and Membrane Permeabilization}

After $48 \mathrm{~h}$ treatment, the cells were washed twice with PBS and incubated with annexin-V-FITC (final concentration $0.25 \mu \mathrm{g} / \mathrm{mL}$ ) for $10 \mathrm{~min}$. Annexin-V binding was measured by the change in fluorescence (F485/530 nm). Membrane permeabilization caused by the investigated compounds was measured using propidium iodide (PI). After $48 \mathrm{~h}$ treatment of the cells, PI was added at a final concentration of $1 \mu \mathrm{g} / \mathrm{mL}$. Intercalation was monitored by the change of fluorescence F535/620 nm. For each of the parameters studied calculations were performed according to the formula:

$$
[\%]=\text { fluorescence of the sample cells/fluorescence of the control cells } \times 100
$$

\subsection{Detection of Mono- and Oligonucleosomes Release (Apoptotic DNA Degradation and Necrosis Detection)}

The late stage of apoptosis was measured by Cell Death Detection ELISA Plus according to the manufacturer's instructions. After $48 \mathrm{~h}$ treatment, the cells were lysed and the levels of histone-complexed DNA fragments (mono- and oligonucleosomes) present in the cytoplasmic fraction were quantified with an immunoreagent complex. The DNA-histone complex served as the positive control (PC). Following the incubation and washes, the colorimetric solution was added and after adding the stop solution, the colorimetric signal was measured at 405 and $490 \mathrm{~nm}$. The calculation of the enrichment factor of the mono- and oligonucleosomes released into the cytoplasm was performed according to the formula:

$$
\begin{aligned}
& \text { Enrichment factor }[\%]=\text { absorbance of the sample cells/absorbance of the control } \\
& \text { cells } \times 100
\end{aligned}
$$

In order to detect necrosis after the cells' incubation with compounds, the medium was collected and the level of DNA fragments released from the necrotic cells was determined analogously to the apoptosis measurement.

\subsection{Fluorescent Microscopic Analysis}

For the DAPI staining, each well of a 8-well Lab-Tek ${ }^{\mathrm{TM}}$ Chamber Slide was seeded with Caco-2 cells $\left(1 \times 10^{4}\right.$ cells/well); for the AO/PI double staining, a 6-well plate was used and each well was 
seeded with $5 \times 10^{4}$ cells/well and incubated for $24 \mathrm{~h}$ to allow them to attach. The tested concentrations of the P. quinquefolium extracts B and Be were 0.137 and $0.274 \mathrm{mg} / \mathrm{mL}$. After $48 \mathrm{~h}$ exposure, the medium with the extracts was gently aspirated. For the AO/PI staining, cells were detached, centrifuged $(182 \times g$, $5 \mathrm{~min})$, decanted and the pellet was stained with the AO $(100 \mu \mathrm{g} / \mathrm{mL})$ and PI $(100 \mu \mathrm{g} / \mathrm{mL}) \mathrm{mixture}(1: 1$, $v / v)$. The morphology of Caco-2 cells was immediately analyzed under a fluorescent microscope with an imaging software (NIS-elements BR 3.0, Nikon, Tokyo, Japan). In the case of DAPI, after treatment, the cells were washed with PBS, fixed with 3.7\% paraformaldehyde for $15 \mathrm{~min}$ at room temperature and air-dried. The cells were then stained with $1 \mu \mathrm{g} / \mathrm{mL}$ of DAPI for $5 \mathrm{~min}$, at an ambient temperature in the dark and observed under the microscope.

\subsection{Statistical Analysis}

All data were presented as the mean $(n \geq 4$ or 8$) \pm$ standard deviation (SD) or standard error of the mean (S.E.M.). All obtained results were subjected to a statistical analysis. The determination comprised the average values and a one-way ANOVA that was followed by the Dunnett's test using the GraphPad prism 4.0 software (GraphPad Software, Inc. La Jolla, CA, USA) or the OriginPro 6.1 software (OriginLab Corporation, Northampton, MA, USA) at the significance level of * $p \leq 0.05$.

\section{Conclusions}

The studied clones of the P. quinquefolium hairy roots were characterized by different ginsenoside profiles and different contents of individual compounds; higher levels of the studied metabolites were observed in the cultures treated with methyl jasmonate. The use of this elicitor significantly stimulated the accumulation of saponins from the Rb group (increase: 2.4-fold, 4.15-fold and 4.7-fold respectively in the A, B and G clones). The effect of methyl jasmonate on the Rg group saponins was ambiguous: a weak stimulant effect was observed for the B and $\mathrm{G}$ clones and an inhibitory effect for clone A.

Here, we also demonstrated the biological activities of the extracts obtained from the P. quinquefolium roots (Figure 9). As intestinal cells are mostly influenced by large quantities of dietary and plant-originated compounds, the human epithelial adenocarcinoma Caco- 2 cell line was chosen as a cellular model. The main aim of our study was to determine the potential for ginsenosides to induce death in cancer cells, i.e., immortalised Caco-2 cells. Importantly, an apoptosis induction was detected at relatively high dosages. Our findings suggest that extracts derived from the elicited P. quinquefolium roots exerted a higher biological activity towards Caco-2 cells than the non-elicited extracts. The elicitation process was associated with significant increases in the $\mathrm{Rb}$ group saponins levels in the root cultures. Among the six studied clones of the P. quinquefolium hairy root extracts, the strongest inhibitors of the cellular metabolic activity, and apoptosis inducers, were extracts B and $\mathrm{B} e$ (elicited). Due to the observed depletion of the mitochondrial membrane potential and ATP level, we suspect that the main inducer of apoptosis was the ROS generation. In this case, extracts with high quantities of ginseng demonstrated a prooxidative activity against cells, probably leading to lipid and protein peroxidation, as well as DNA damage.

Moreover, Caco-2 cells are also used as a model of artificial intestine, as they maintain part of the functional capacity of the epithelium in vitro, and are commonly used for in vitro studies of the mechanism of intestinal absorption, and of the cytoprotection against oxidative stress or DNA and proteins damage. It is known that P. quinquefolium phytocompounds are able decrease intracellular oxidative stress via chemical radical scavenging, or the recovery and activation of intracellular enzymatic defence, i.e., (glutathione peroxidase (GPx) or superoxide dismutase (SOD) [3]. We are aware that the presented study lacks the presentation of the cytoprotective potential of the obtained ginsenosides. The influence of the obtained extracts as cytoprotective agents and regulators of cellular signalling at non-cytotoxic concentrations will be examined in more detail in further studies. In summary, our findings indicate that further research concerning P. quinquefolium hairy root cultures should focus on the examination of rare ginsenosides and other biologically active compound profiles, 
i.e., phenolic compounds, in order to fully explain the biological properties of P. quinquefolium hairy root cultures.

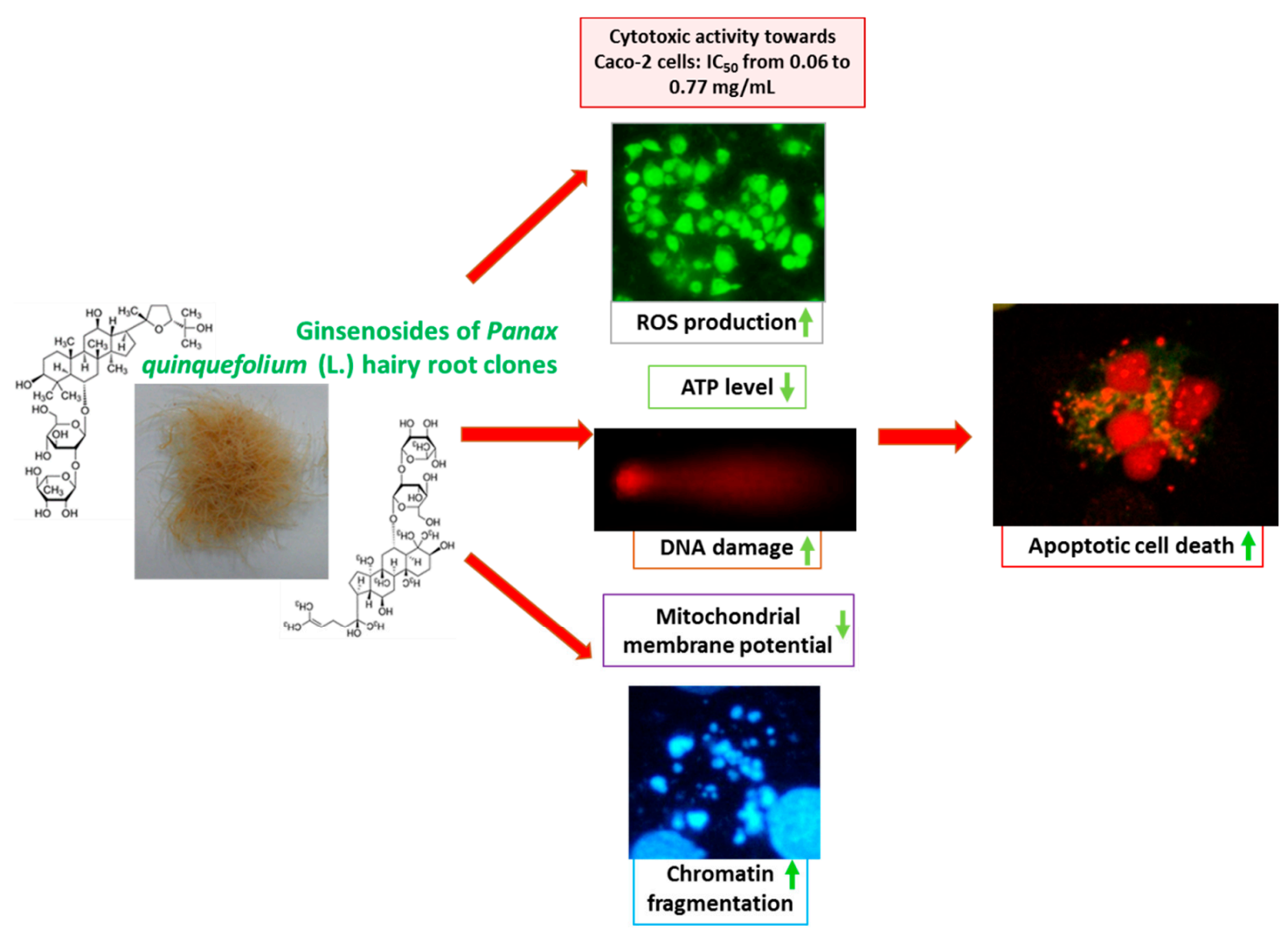

Figure 9. P. quinquefolium ginsenosides as agents able to induce apoptosis in Caco-2 cells—proposed mechanism of action.

Supplementary Materials: The following is available online, Figure S1: The percentage of individual saponins in relation to the total ginsenoside content in hairy root cultures untreated and treated with MeJa.

Author Contributions: E.K. conceptualization, supervision, methodology, lab work and results-hairy root cultures, extracts, HPLC; writing - original draft preparation, review and editing; A.N. methodology, lab work and results-cyto- and genotoxicity testing, ROS detection, microscopic analysis; writing-original draft preparation, review and editing; M.Z.-S. methodology, lab work and results-ROS detection, MMP, ATP, apoptosis, necrosis; writing - original draft preparation, review and editing; D.S. help in cyto- and genotoxicity testing; help in writing; G.S. methodology, lab work and results—hairy root cultures, extracts, HPLC; writing - original draft preparation, review and editing; I.M. writing-review and editing. All authors have read and agreed to the published version of the manuscript.

Funding: This research received no external funding.

Conflicts of Interest: The authors declare no conflict of interest.

\section{References}

1. Pengelly, A.K.; Bennett, K. Appalachian Plant Monographs: Panax quinquefolius L., American Ginseng. Available online: http://www.frostburg.edu/aces/appalachian-plants/ (accessed on 5 January 2019).

2. Metwaly, A.M.; Lianlian, Z.; Luqi, H.; Deqiang, D. Black Ginseng and Its Saponins: Preparation, Phytochemistry and Pharmacological Effects. Molecules 2019, 24, 1856. [CrossRef]

3. Szczuka, D.; Nowak, A.; Zakłos-Szyda, M.; Kochan, E.; Szymańska, G.; Motyl, I.; Blasiak, J. American Ginseng (Panax quinquefolium L.) as a Source of Bioactive Phytochemicals with Pro-Health Properties. Nutrients 2019, 11, 1041. [CrossRef] 
4. Quan, K.; Liu, Q.; Wan, J.-Y.; Zhao, Y.-J.; Guo, R.-Z.; Alolga, R.N.; Li, P.; Qi, L.-W. Rapid preparation of rare ginsenosides by acid transformation and their structure-activity relationships against cancer cells. Sci. Rep. 2015, 5, 8598. [CrossRef]

5. Mohanan, P.; Subramaniyam, S.; Mathiyalagan, R.; Yang, D.-C. Molecular signaling of ginsenosides Rb1, Rg1, and Rg3 and their mode of actions. J. Ginseng Res. 2018, 42, 123-132. [CrossRef]

6. Guo, D.; Cheng, L.; Zhang, Y.; Zheng, H.; Ma, H.; Li, L. An improved method for the preparation of Ginsenoside Rg5 from ginseng fibrous root powder. Heliyon 2019, 5, e02694. [CrossRef]

7. An, K.S.; Choi, Y.O.; Lee, S.M.; Ryu, H.Y.; Kang, S.J.; Yeon, Y.; Kim, Y.R.; Lee, J.G.; Kim, C.J.; Lee, Y.J.; et al. Ginsenosides Rg5 and Rk1 Enriched Cultured Wild Ginseng Root Extract Bioconversion of Pediococcus pentosaceus HLJG0702: Effect on Scopolamine-Induced Memory Dysfunction in Mice. Nutrients 2019, 11, 1120. [CrossRef]

8. Leung, K.; Wong, A. Pharmacology of ginsenosides: A literature review. Chin. Med. 2010, 5, 20. [CrossRef] [PubMed]

9. Cruse-Sanders, J.M.; Hamrick, J.L. Genetic diversity in harvested and protected populations of wild American ginseng, Panax quinquefolius L. (Araliaceae). Am. J. Bot. 2004, 91, 540-548. [CrossRef] [PubMed]

10. Proctor, J.T.A.; Shelp, B.J. Effect of boron nutrition on American ginseng in field and in nutrient cultures. J. Ginseng Res. 2014, 38, 73-77. [CrossRef] [PubMed]

11. Jia, L.; Zhao, Y. Current Evaluation of the Millennium Phytomedicine- Ginseng (I): Etymology, Pharmacognosy, Phytochemistry, Market and Regulations. Curr. Med. Chem. 2009, 16, 2475-2484. [CrossRef] [PubMed]

12. Smetanska, I. Production of Secondary Metabolites Using Plant Cell Cultures. In Food Biotechnology; Stahl, U., Donalies, U.E.B., Nevoigt, E., Eds.; Advances in Biochemical Engineering/Biotechnology; Springer Berlin Heidelberg: Berlin/Heidelberg, Germany, 2008; Volume 111, pp. 187-228, ISBN 978-3-540-70535-2.

13. Mehrotra, S.; Mishra, S.; Srivastava, V. Bioreactor Technology for Hairy Roots Cultivation. In Bioprocessing of Plant In Vitro Systems; Pavlov, A., Bley, T., Eds.; Springer International Publishing: Cham, Switzerlan, 2016; pp. 1-25, ISBN 978-3-319-32004-5.

14. Kochan, E.; Szymczyk, P.; Kuźma, Ł.; Szymańska, G. Nitrogen and phosphorus as the factors affecting ginsenoside production in hairy root cultures of Panax quinquefolium cultivated in shake flasks and nutrient sprinkle bioreactor. Acta Physiol. Plant. 2016, 38, 149. [CrossRef]

15. Kochan, E.; Balcerczak, E.; Lipert, A.; Szymańska, G.; Szymczyk, P. Methyl jasmonate as a control factor of the synthase squalene gene promoter and ginsenoside production in American ginseng hairy root cultured in shake flasks and a nutrient sprinkle bioreactor. Ind. Crops Prod. 2018, 115, 182-193. [CrossRef]

16. Kochan, E.; Królicka, A.; Chmiel, A. Growth and ginsenoside production in Panax quinquefolium hairy roots cultivated in flasks and nutrient sprinkle bioreactor. Acta Physiol. Plant. 2012, 34, 1513-1518. [CrossRef]

17. Ramirez-Estrada, K.; Vidal-Limon, H.; Hidalgo, D.; Moyano, E.; Golenioswki, M.; Cusidó, R.; Palazon, J. Elicitation, an Effective Strategy for the Biotechnological Production of Bioactive High-Added Value Compounds in Plant Cell Factories. Molecules 2016, 21, 182. [CrossRef] [PubMed]

18. Kim, O.T.; Bang, K.H.; Kim, Y.C.; Hyun, D.Y.; Kim, M.Y.; Cha, S.W. Upregulation of ginsenoside and gene expression related to triterpene biosynthesis in ginseng hairy root cultures elicited by methyl jasmonate. Plant. Cell Tissue Organ. Cult. PCTOC 2009, 98, 25-33. [CrossRef]

19. Hayta, S.; Gurel, A.; Akgun, I.; Altan, F.; Ganzera, M.; Tanyolac, B.; Bedir, E. Induction of Gentiana cruciata hairy roots and their secondary metabolites. Biologia (Bratisl.) 2011, 66, 618-625. [CrossRef]

20. Wang, H.; Gao, S.; da Silva, J.A.T.; Ma, G. Agrobacterium rhizogenes-mediated genetic transformation of Psammosilene tunicoides and identification of high saponin-yielding clones. Environ. Exp. Biol. 2015, 13, $19-23$.

21. Bulgakov, V.P. Functions of rol genes in plant secondary metabolism. Biotechnol. Adv. 2008, 26, 318-324. [CrossRef]

22. Sujatha, M.; Vijay, S.; Vasavi, S.; Veera Reddy, P.; Chander Rao, S. Agrobacterium-mediated transformation of cotyledons of mature seeds of multiple genotypes of sunflower (Helianthus annuus L.). Plant Cell Tissue Organ. Cult. PCTOC 2012, 110, 275-287. [CrossRef]

23. Shkryl, Y.N.; Veremeichik, G.N.; Bulgakov, V.P.; Tchernoded, G.K.; Mischenko, N.P.; Fedoreyev, S.A.; Zhuravlev, Y.N. Individual and combined effects of the rol A,B, and $\mathrm{C}$ genes on anthraquinone production in Rubia cordifolia transformed calli. Biotechnol. Bioeng. 2008, 100, 118-125. [CrossRef] 
24. Nowak, A.; Zakłos-Szyda, M.; Żyżelewicz, D.; Koszucka, A.; Motyl, I. Acrylamide Decreases Cell Viability, and Provides Oxidative Stress, DNA Damage, and Apoptosis in Human Colon Adenocarcinoma Cell Line Caco-2. Molecules 2020, 25, 368. [CrossRef]

25. Jeong, Y.; Ku, S.; You, H.J.; Ji, G.E. A stereo-selective growth inhibition profile of ginsenoside Rh2 on human colon cancer cells. CyTA-J. Food 2019, 17, 488-493. [CrossRef]

26. Chen, W.; Balan, P.; Popovich, D.G. Analysis of Ginsenoside Content (Panax ginseng) from Different Regions. Molecules 2019, 24, 3491. [CrossRef]

27. Ahuja, A.; Kim, J.H.; Kim, J.-H.; Yi, Y.-S.; Cho, J.Y. Functional role of ginseng-derived compounds in cancer. J. Ginseng Res. 2018, 42, 248-254. [CrossRef] [PubMed]

28. Kang, O.-J.; Kim, J.-S. Comparison of Ginsenoside Contents in Different Parts of Korean Ginseng (Panax ginseng C.A. Meyer). Prev. Nutr. Food Sci. 2016, 21, 389-392. [CrossRef] [PubMed]

29. Wang, C.-Z.; Anderson, S.; Du, W.; He, T.-C.; Yuan, C.-S. Red ginseng and cancer treatment. Chin. J. Nat. Med. 2016, 14, 7-16. [PubMed]

30. Luo, X.; Wang, C.-Z.; Chen, J.; Song, W.-X.; Luo, J.; Tang, N.; He, B.-C.; Kang, Q.; Wang, Y.; Du, W.; et al. Characterization of gene expression regulated by American ginseng and ginsenoside Rg3 in human colorectal cancer cells. Int. J. Oncol. 2008, 32, 975-983. [CrossRef]

31. Qu, Y.; Wang, Z.; Zhao, F.; Liu, J.; Zhang, W.; Li, J.; Song, Z.; Xu, H. AFM-detected apoptosis of hepatocellular carcinoma cells induced by American ginseng root water extract. Micron 2018, 104, 1-7. [CrossRef]

32. Kim, J.H.; Bae, Y.C.; Lee, J.W.; Choi, J.S.; Bae, S.H. Effects of ginsenoside Rg3 on apoptosis in A375.S2 melanoma cells. Transl. Cancer Res. 2019, 8, 357-366. [CrossRef]

33. Li, T.; Sun, W.; Dong, X.; Yu, W.; Cai, J.; Yuan, Q.; Shan, L.; Efferth, T. Total ginsenosides of Chinese ginseng induces cell cycle arrest and apoptosis in colorectal carcinoma HT-29 cells. Oncol. Lett. 2018, 16, 4640-4648. [CrossRef]

34. Zhang, Y.-H.; Li, H.-D.; Li, B.; Jiang, S.-D.; Jiang, L.-S. Ginsenoside Rg3 induces DNA damage in human osteosarcoma cells and reduces MNNG-induced DNA damage and apoptosis in normal human cells. Oncol. Rep. 2014, 31, 919-925. [CrossRef] [PubMed]

35. Baskic, D.; Popovic, S.; Ristic, P.; Arsenijevic, N. Analysis of cycloheximide-induced apoptosis in human leukocytes: Fluorescence microscopy using annexin V/propidium iodide versus acridin orange/ethidium bromide. Cell Biol. Int. 2006, 30, 924-932. [CrossRef] [PubMed]

36. Salim, L.; Mohan, S.; Othman, R.; Abdelwahab, S.; Kamalidehghan, B.; Sheikh, B.; Ibrahim, M. Thymoquinone Induces Mitochondria-Mediated Apoptosis in Acute Lymphoblastic Leukaemia in Vitro. Molecules 2013, 18, 11219-11240. [CrossRef] [PubMed]

37. Chen, F.; Sun, Y.; Zheng, S.-L.; Qin, Y.; Julian McClements, D.; Hu, J.-N.; Deng, Z.-Y. Antitumor and immunomodulatory effects of ginsenoside $\mathrm{Rh} 2$ and its octyl ester derivative in $\mathrm{H} 22$ tumor-bearing mice. J. Funct. Foods 2017, 32, 382-390. [CrossRef]

38. Duan, Z.; Deng, J.; Dong, Y.; Zhu, C.; Li, W.; Fan, D. Anticancer effects of ginsenoside Rk3 on non-small cell lung cancer cells: In vitro and in vivo. Food Funct. 2017, 8, 3723-3736. [CrossRef]

39. Wang, J.; Tian, L.; Khan, M.N.; Zhang, L.; Chen, Q.; Zhao, Y.; Yan, Q.; Fu, L.; Liu, J. Ginsenoside Rg3 sensitizes hypoxic lung cancer cells to cisplatin via blocking of NF- $\mathrm{kB}$ mediated epithelial-mesenchymal transition and stemness. Cancer Lett. 2018, 415, 73-85. [CrossRef]

40. Choi, J.-S.; Chun, K.-S.; Kundu, J.; Kundu, J.K. Biochemical basis of cancer chemoprevention and/or chemotherapy with ginsenosides (Review). Int. J. Mol. Med. 2013, 32, 1227-1238. [CrossRef]

41. Oh, J.-M.; Kim, E.; Chun, S. Ginsenoside Compound K Induces Ros-Mediated Apoptosis and Autophagic Inhibition in Human Neuroblastoma Cells In Vitro and In Vivo. Int. J. Mol. Sci. 2019, 20, 4279. [CrossRef]

42. Liu, Y.; Fan, D. Ginsenoside Rg5 induces apoptosis and autophagy via the inhibition of the PI3K/Akt pathway against breast cancer in a mouse model. Food Funct. 2018, 9, 5513-5527. [CrossRef]

43. Li, B.; Zhao, J.; Wang, C.-Z.; Searle, J.; He, T.-C.; Yuan, C.-S.; Du, W. Ginsenoside Rh2 induces apoptosis and paraptosis-like cell death in colorectal cancer cells through activation of p53. Cancer Lett. 2011, 301, 185-192. [CrossRef]

44. Galluzzi, L.; Vitale, I.; Aaronson, S.A.; Abrams, J.M.; Adam, D.; Agostinis, P.; Alnemri, E.S.; Altucci, L.; Amelio, I.; Andrews, D.W.; et al. Molecular mechanisms of cell death: Recommendations of the Nomenclature Committee on Cell Death 2018. Cell Death Differ. 2018, 25, 486-541. [CrossRef] 
45. Hong, S.; Hwang, H.-J.; Kim, J.W.; Kim, J.A.; Lee, Y.B.; Roh, E.; Choi, K.M.; Baik, S.H.; Yoo, H.J. Ginsenoside compound-Mc1 attenuates oxidative stress and apoptosis in cardiomyocytes through an AMP-activated protein kinase-dependent mechanism. J. Ginseng Res. 2019, S1226845318304202. [CrossRef]

46. Kochan, E.; Szymczyk, P.; Kuźma, Ł.; Szymańska, G.; Wajs-Bonikowska, A.; Bonikowski, R.; Sienkiewicz, M. The Increase of Triterpene Saponin Production Induced by Trans-Anethole in Hairy Root Cultures of Panax quinquefolium. Molecules 2018, 23, 2674. [CrossRef] [PubMed]

47. Nowak, A.; Sójka, M.; Klewicka, E.; Lipińska, L.; Klewicki, R.; Kołodziejczyk, K. Ellagitannins from Rubus idaeus L. Exert Geno- and Cytotoxic Effects against Human Colon Adenocarcinoma Cell Line Caco-2. J. Agric. Food Chem. 2017, 65, 2947-2955. [CrossRef] [PubMed]

48. OECD/OCDE TG 442D Adopted: February 2015 OECD Guideline For The Testing Of Chemicals In Vitro Skin Sensitisation: ARE-Nrf2 Luciferase Test Method 2015. Available online: https://www.oecd-ilibrary.org/ environment/test-no-442d-in-vitro-skin-sensitisation_9789264229822-en (accessed on 13 January 2020).

49. Choi, Y.H. Schisandrin A prevents oxidative stress-induced DNA damage and apoptosis by attenuating ROS generation in C2C12 cells. Biomed. Pharmacother. 2018, 106, 902-909. [CrossRef]

Sample Availability: Samples of the compounds are available from the authors.

(C) 2020 by the authors. Licensee MDPI, Basel, Switzerland. This article is an open access article distributed under the terms and conditions of the Creative Commons Attribution (CC BY) license (http://creativecommons.org/licenses/by/4.0/). 